\title{
Production of $\beta$-Lactamase Inhibitors by Streptomyces Species
}

\author{
Daniela de Araújo Viana Marques ${ }^{1, *}$, Suellen Emilliany Feitosa Machado ${ }^{2}$, \\ Valéria Carvalho Santos Ebinuma ${ }^{3}$ (i) , Carolina de Albuquerque Lima Duarte ${ }^{4}$, \\ Attilio Converti ${ }^{5}$ and Ana Lúcia Figueiredo Porto ${ }^{6}$ \\ 1 Campus Serra Talhada, University of Pernambuco, Avenida Custódio Conrado, 600, AABB, \\ Serra Talhada, Pernambuco 56912-550, Brazil \\ 2 Department of Antibiotics, Federal University of Pernambuco, Avenida da Engenharia, $2^{\circ}$ andar, \\ Cidade Universitária, Recife, Pernambuco 50740-600,Brazil; suellen_feitosa_@hotmail.com \\ 3 Department of Bioprocesses and Biotechnology, School of Pharmaceutical Sciences, \\ São Paulo State University (UNESP), Rodovia Araraquara-Jaú/Km 01, Araraquara 14800-903, Brazil; \\ valeriac@fcfar.unesp.br \\ 4 Campus Garanhuns, University of Pernambuco, Rua Capitão Pedro Rodrigues, 105, São José, Garanhuns, \\ Pernambuco 55295-110, Brazil; carolina.albuquerque@upe.br \\ 5 Department of Civil, Chemical and Environmental Engineering, Chemical Pole, University of Genoa, \\ Via Opera Pia 15, 16145 Genoa, Italy; converti@unige.it \\ 6 Department of Morphology and Animal Physiology, Federal Rural University of Pernambuco, \\ Av. Dom Manoel de Medeiros, Recife, Pernambuco 52171-900, Brazil; analuporto@yahoo.com.br \\ * Correspondence: daniela_viana@yahoo.com.br; Tel.: +55-81-995047420
}

Received: 30 May 2018; Accepted: 12 July 2018; Published: 17 July 2018

\begin{abstract}
Lactamase inhibitors have emerged as an effective alternative to reduce the effects of resistance against $\beta$-lactam antibiotics. The Streptomyces genus is known for being an exceptional natural source of antimicrobials and $\beta$-lactamase inhibitors such as clavulanic acid, which is largely applied in clinical practice. To protect against the increasing prevalence of multidrug-resistant bacterial strains, new antibiotics and $\beta$-lactamase inhibitors need to be discovered and developed. This review will cover an update about the main $\beta$-lactamase inhibitors producers belonging to the Streptomyces genus; advanced methods, such as genetic and metabolic engineering, to enhance inhibitor production compared with wild-type strains; and fermentation and purification processes. Moreover, clinical practice and commercial issues are discussed. The commitment of companies and governments to develop innovative strategies and methods to improve the access to new, efficient, and potentially cost-effective microbial products to combat the antimicrobial resistance is also highlighted.
\end{abstract}

Keywords: actinobacteria; $\beta$-lactamase; resistance; antibiotic; $\beta$-lactamase inhibitor

\section{Introduction}

Infectious diseases, which are caused by bacteria, viruses, parasites, or fungi, persist to be the main cause of mortality worldwide. Despite the success of antibiotics and advances in their production and purification, children and old people are affected by bacterial infections that cause approximately 17 million deaths per year. One of the main reasons for this occurrence is the increasing prevalence of antibiotic-resistant strains [1].

Penicillin was the first antibiotic discovered by Alexander Fleming in 1928, and since then, these compounds have been essential for healthcare [2]. Although the first antibiotic producer discovered was a Penicillium strain, many others have this potential, and since 1942, the Streptomyces 
genus has been known for its extraordinary ability to produce secondary metabolites, mainly antibiotics; nearly two-thirds of which occur naturally. This genus is one of the largest genera as it contains over 500 species, described along with a variety of species recognized as Actinomycetes [3,4].

Streptomyces are among the most versatile soil microorganisms, given their high metabolite production rate and the large variety of biotransformations. Overall, intracellular mechanisms control the accumulation of metabolites, which depends on process variables, types of nutrients, their concentrations, and operating conditions in submerged culture $[5,6]$. Therefore, the study and selection of appropriate culture medium composition is essential to ensure high productivity and low costs of the production process [7]. Additionally, many natural antibiotics must be purified after the production process through cost-effective methods that enable one to recover the final product at the highest level of purity and yield [8].

The first Streptomyces species used in industrial antibiotic production were S. griseus and S. venezuelae, which allowed one to obtain streptomycin and chloromycetin, respectively [8]. Since then, a large number of antibiotics (over $55 \%$ of available antibiotics) produced by the genus Streptomyces were detected between 1945 and 1978 [9].

The first important antibiotic used in clinical practice was penicillin $G$ (benzylpenicillin), a $\beta$-lactam compound that attracted the interest of researchers to develop other derivatives. The $\beta$-lactam ring present in the structure of this drug, which is typical of this class of antibiotics, acts by linking intimately to the penicillin-binding proteins (transpeptidases), affecting cell wall biosynthesis in both Gram-negative and Gram-positive bacteria [10,11].

Afterwards, as a result of quick replication, recombination, and the high mutation rate of bacteria, resistance to $\beta$-lactam antibiotics emerged among the $\beta$-lactamase-producing organisms. These enzymes act directly on the $\beta$-lactam ring, inactivating the antibiotic. The first $\beta$-lactamase was a plasmid-mediated enzyme [12], named TEM from the name (Temoniera) of a patient in which the enzyme-producing E. coli strain was isolated. Subsequently, a plasmid with similar biochemical properties was detected and named TEM-2. Faced with this fact, the efforts to discover inhibitors able to inactivate $\beta$-lactamases began around 1970. Among them, clavulanic acid, which was obtained by screening of natural products, and possesses a similar $\beta$-lactam ring, was found to be a potent inhibitor of staphylococcal penicillinases and other plasmid-encoded penicillinases present in enteric bacteria, including TEM [13].

Nevertheless, antibiotic resistance was not over, and other bacteria began to produce similar enzymes; thus, the main challenge would be discovering novel inhibitors with activity against a broad spectrum of enzymes from multiple classes [10]. Genetic engineering has been an alternative tool to achieve this aim; thanks to a better knowledge of the expression of regulatory proteins in mutant organisms, it suggested that antibiotic production might be influenced by these regulatory events [14].

In accordance with the points explained above, this review provides a summary of the $\beta$-lactamase inhibitors produced by Streptomyces species. Herein, we emphasize some topics such as antibiotic resistance, $\beta$-lactamases inhibitor producers, production and purification processes, use of $\beta$-lactamase inhibitors in clinical practice, and commercial aspects.

\section{Antibiotic Resistance}

As previously mentioned, antibiotics produced by Streptomyces spp. were detected in 1942 with the discovery of streptomycin, and since then, researchers intensified the search for similar antibiotics within this genus [15].

However, as a mechanism of resistance, bacteria started to produce enzymes with the capacity to hydrolyze $\beta$-lactam antibiotics ( $\beta$-lactamases), hence decreasing their efficiency. Meanwhile, penicillin-resistant strains of Staphylococcus aureus and Streptococcus pneumoniae emerged, which led to the proposition that the resistance mechanism could be intrinsically associated with the genomes of these bacteria [16-20]. The same phenomenon was observed with Gram-negative bacteria belonging to the Neisseria genus [21] and other streptomycin-resistant bacteria [22]. Biofilm formation by 
microorganisms is also allied with chronic, recurrent human infections and resistance [23]. The spread of resistant strains is linked to the migration of people as well, who dissipate resistant strains among population in remote communities where the use of antibiotics is very restricted [24].

In a bacterial infection, antibiotics act in two stages: in the former, a large part of the bacterial cells are killed, while in the latter, a few of them stay alive and are called persistent bacteria. If the antibiotic is withdrawn, these survivors begin a new multiplication, leading to a slow elimination of infection and recurrent bacterial infections. This phenomenon, which is called persistent sub-minimum inhibitory concentration (MIC), is observed in most bacteria. For instance, tuberculosis, which is caused by Mycobacterium tuberculosis, is treated for at least six months, and when the treatment is not continuous, recurrence of infection is commonly observed. Although different from resistant bacteria, the persistent ones are of great concern to the medical field, and the study and knowledge of the mechanisms of this phenomenon are of paramount importance [25].

These sub-MICs suggest a greater selection of resistance, increase bacterial mutation rates, cause phenotypic and genotypic variability, and affect the biofilm formation. In addition, they promote the maintenance of horizontal transmission of resistance genes [26] and can be especially important in multispecies communities, where even small changes in species interaction can have cascading effects [27].

Many Gram-negative bacteria, such as Haemophilus influenza; Klebsiella pneumonia; Acinetobacter baumanii; Pseudomonas aeruginosa; Enterobacter spp.; Escherichia coli; Serratia spp.; Proteus spp.; Providencia spp.; Helicobacter pylori; Salmonella spp.; Neisseria gonorrhoeae; Shigella spp.; and some Gram-positive ones such as Enterococcus faecium, S. aureus, and S. pneumoniae, were classified by the World Health Organization (WHO) as "ESKAPE" pathogens, with an extremely important role in the antimicrobial resistance era $[28,29]$.

In addition, another interesting theory was that, unlike antibiotic-producing fungi, Streptomyces species defend themselves from antimicrobial attach. These microorganisms possess a self-resistance mechanism to avert the suicide, which made the antimicrobial resistance appear as a natural event preceding the current selective pressure of clinical antibiotic use [30]. The main mechanisms involved in $\beta$-lactam antibiotic resistance are inactivation of $\beta$-lactamases and modification of penicillin-binding proteins (PBPs). Furthermore, about 90 years after penicillin discovery, $\beta$-lactam-based therapies have been largely used against some illness. It is known that the chemical structures of drugs have greatly been modified in the recent past, and this action has become the tactic for most of currently-available antibiotics, which are known as second-, third-, and fourth-generation antibiotics [31,32]. Despite this progress, the indiscriminate use of antibiotics may be responsible for a microbial war in the near future [33].

Beta-Lactam antibiotics were also the first natural antibacterial compounds to be successfully developed and modified by the pharmaceutical industry [34]. This class of compounds has in common a $\beta$-lactam four-membered ring associated with different structures (Figure 1). They act by inhibiting bacterial cell wall peptidoglycan biosynthesis, thereby leading to cell lysis and death $[35,36]$. Specifically, $\beta$-lactam antibiotics bind to the acylate active site of PBPs, which is essential for the bacteria cell wall biosynthesis [37].

Beta-Lactam antibiotics have been widely employed for several years to treat infectious diseases because of their high specificity and strong killing efficiency [37]; however, bacterial capacity to develop apparatuses of resistance to $\beta$-lactam drugs is one of the big problems of health care [37,38]. Among the mechanisms of antibiotic resistance, we can cite the production of efflux pumps, modification or reduced production of outer membrane porins (in Gram-negative bacteria), alteration of PBPs (the molecular target of $\beta$-lactams), and production of $\beta$-lactamases [39]. In this review, we will focus on the last resistance mechanism and the mode to overcome this problem by means of biotechnology. 


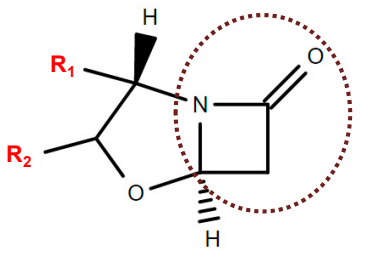

Clavam

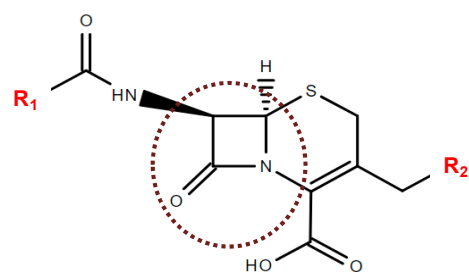

Cephalosporin

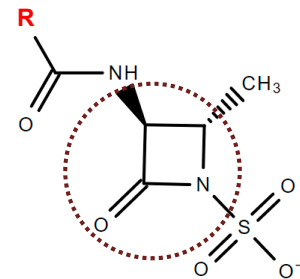

Monobactam

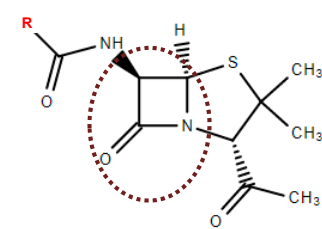

Penicillin

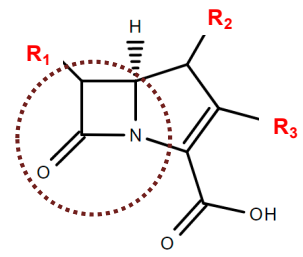

Carbapenem

Figure 1. Backbone composition of $\beta$-lactam structures with the $\beta$-lactam ring highlighted (Structures drawn in ChemSpider).

\section{Producers of $\beta$-Lactamases}

Because $\beta$-lactamases act by breaking the amide bond present in the $\beta$-lactam ring of penicillins, they inactivate the drug biological activity, resulting in the inability of antibiotics to kill bacterial cells [40]. The microbial production of these enzymes strongly depends on cell structure. Gram-negative bacteria, with their inner and outer cell membranes separated from the periplasmic space, might be considered more developed microorganisms than the Gram-positive ones, which possess only a rigid cell wall composed of several peptidoglycan layers. As a result, Gram-negative bacteria produce high amounts of $\beta$-lactamases compared with the Gram-positive ones. Beta-Lactamase production by the former group can occur by induction (direct interaction of a $\beta$-lactam with the microorganism regulatory system) or constitutively, while that by Gram-positive bacteria is not yet well understood [37]. Among the Gram-negative bacteria, the $\beta$-lactamase production level can vary greatly; as an example, the active $\beta$-lactamase level in some enteric bacteria can exceed $4 \%$ of total soluble protein [41].

The enzyme characteristics are quite dependent on the original host. More than 1600 proteins with capacity to hydrolyze $\beta$-lactam rings have already been described [42], which, on one hand, demonstrates the diversity of $\beta$-lactamase structure [43], but from the other, hinders understanding of their action mechanism [42]. Efforts have been made to classify these enzymes, which were mainly based on their molecular structure (full nucleotide, amino acid sequence, and conserved motifs), functional characteristics (including substrate and inhibition profiles), or variances in structural features [43]. According to Ambler classification, $\beta$-lactamases are grouped in classes A, B, C, and D. Classes A, C, and D include enzymes that use serine in their active site to hydrolyze the substrate forming the acyl enzyme, while those belonging to class B are metallo- $\beta$-lactamases that require a bivalent ion, usually $\mathrm{Zn}^{2+}$, for the hydrolysis $[10,44]$.

On the other hand, Bush, Jacoby, and Medeiros in 1995 [43] classified $\beta$-lactamases in four groups based on their functional features: (1) cephalosporinases not fully inhibited by clavulanic acid; (2) penicillinases, cephalosporinases, and broad-spectrum $\beta$-lactamases inhibited by active site-directed inhibitors of $\beta$-lactamases; and (3) metallo- $\beta$-lactamases that are able to hydrolyze the main $\beta$-lactam antibiotics, but are scarcely inhibited by typical inhibitors of $\beta$-lactamases.

Later, Bush and Jacoby [44] expanded this classification to include subgroups with more recently discovered $\beta$-lactamases. As an example, the group $2 \mathrm{~d}$ comprises the OXA enzymes (oxacillinases) that can hydrolyze cloxacillin and oxacillin [44]. Table 1 summarizes the groups of $\beta$-lactamases, while deeper description can be found in the work of Bush and Jacoby [44]. 
Table 1. Classification of $\beta$-lactamases based on Bush and Jacoby [44].

\begin{tabular}{|c|c|c|}
\hline $\begin{array}{l}\text { Functional Group According Bush, Jacoby, } \\
\text { and Medeiros * }\end{array}$ & Ambler Class * & Hydrolyzed $\beta$-Lactam Antibiotics \\
\hline 1 & $\mathrm{C}$ & Cephalosporins, benzylpenicillin, cephamycins \\
\hline $1 \mathrm{e}$ & $\mathrm{C}$ & Ceftazidime and often other oxyimino- $\beta$-lactams \\
\hline \multirow{12}{*}{2} & A & Benzylpenicillin \\
\hline & A & Benzylpenicillin and cephalosporins \\
\hline & $\mathrm{A}$ & $\begin{array}{l}\text { Cefotaxime, ceftazidime, ceftriaxone, cefepime, } \\
\text { aztreonam }\end{array}$ \\
\hline & A & $\begin{array}{l}\text { Resistance to clavulanic acid, sulbactam, } \\
\text { and tazobactam }\end{array}$ \\
\hline & A & $\begin{array}{l}\text { Oxyimino- } \beta \text {-lactams combined with resistance to } \\
\text { clavulanic acid, sulbactam, and tazobactam }\end{array}$ \\
\hline & A & Carbenicillin \\
\hline & A & Carbenicillin, cefepime, and cefpirome \\
\hline & $\mathrm{D}$ & Cloxacillin or oxacillin \\
\hline & $\mathrm{D}$ & Cloxacillin or oxacillin, and oxyimino- $\beta$-lactams \\
\hline & $\mathrm{D}$ & Cloxacillin or oxacillin and carbapenems \\
\hline & A & Cephalosporins inhibited by clavulanic acid \\
\hline & A & Carbapenems, oxyimino- $\beta$-lactams, cephamycins \\
\hline 3 & B & Carbapenems \\
\hline 4 & Unknown & Carbapenems \\
\hline
\end{tabular}

According to the work of Laxminarayan et al. published in 2016, around 214,000 neonatal sepsis deaths worldwide are related to resistant pathogens each year [45]. To overcome the problem of antimicrobial resistance due to $\beta$-lactamase production, the pharmaceutical industry has employed two strategies: (i) improvement of $\beta$-lactam antibiotics resistant to these enzymes (as an example, the expanded-spectrum cephalosporins and carbapenems); and (ii) the application of $\beta$-lactamase inhibitors (BLIs) associated with a $\beta$-lactam antibiotic [34]. However, the first strategy has not demonstrated to be so effective because bacteria have developed the capacity to produce enzymes with enhanced features such as extended-spectrum $\beta$-lactamases (ESBLs) [40] and carbapenemases [45]. Therefore, application of BLIs may be a valid approach to overcome the problem of antimicrobial resistance.

\section{Inhibitors of $\beta$-Lactamases}

Although resembling $\beta$-lactam antibiotic structure, BLIs are compounds with weak antibacterial activity. Thus, the therapeutic strategy is to co-administer BLIs with penicillins and cephalosporins [36] in two different ways: (i) employing substrates that bind the enzyme reversibly and/or irreversibly, forming unfavorable steric interactions; or (ii) developing mechanism-based or irreversible "suicide inhibitors" as clavulanic acid (CA), sulbactam, and tazobactam (Figure 2) [10,46].

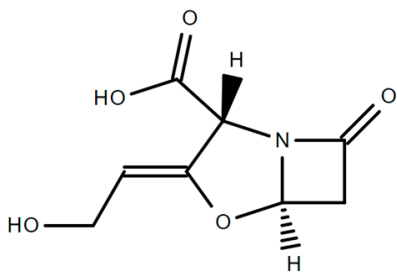

Clavulanic acid

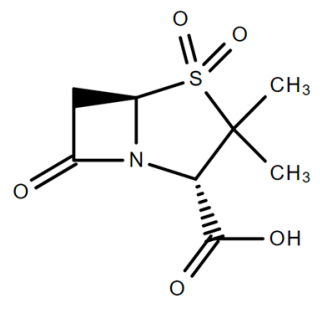

Sulbactam

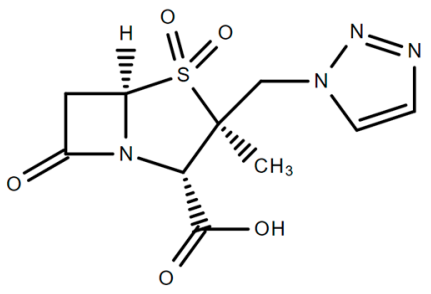

Tazobactam

Figure 2. Chemical structure of $\beta$-lactamase inhibitors (Structures drawn in ChemSpider). 
CA is a natural drug isolated in 1976 from Streptomyces clavuligerus fermentation broth [41], while sulbactam and tazobactam are BLIs developed by synthetic route in 1980 [40]. CA binds irreversibly with the serine hydroxyl group present in the active site of the enzyme, producing a stable acylated intermediate and inactivating the enzyme. As a result, the antibiotic co-administered with CA performs its main action [47]. Augmentin ${ }^{\mathrm{TM}}$ (amoxicillin and potassium clavulanate) [40] and Timentin ${ }^{\mathrm{TM}}$ (ticarcillin and potassium clavulanate) [47], both produced by GlaxoSmithKline [10], are examples of combinations available in the market. Drugs combined with CA have proven clinical efficacy against several bacteria (both Gram-negative and Gram-positive) as described by Drawz and Bonomo [10]. CA is associated with other $\beta$-lactam antibiotics in its salt form because of its instability under several conditions, such as acidic or alkaline conditions, and in the presence of salts [36].

Sulbactam and tazobactam have inhibitory spectra and mechanisms similar to those of CA [40]. Sulbactam is available on the medicine market in combination with ampicillin (Unasyn ${ }^{\mathrm{TM}}$ produced by Pfizer) and cefoperazone (Magnex ${ }^{\mathrm{TM}}$ produced by Pfizer) [10]. Sulbactam has advantages compared with other BLIs because it has its own activity against some Acinetobacter baumannii strains and does not induce class I (Ampc) chromosomal $\beta$-lactamases in Enterobacteriaceae [48]. Moreover, sulbactam combinations have not demonstrated strong selective pressures for ESBL-producing Enterobacteriaceae and vancomycin-resistant enterococci [48].

Tazobactam combined with piperacillin (Zosyn ${ }^{\mathrm{TM}}$ produced by Wyeth) has proven clinical efficacy against Gram-positive and Gram-negative pathogens [10]. Tazobactam was also associated with Ceftolozane being an antibacterial agent with potent activity against Gram-negative bacteria, including drug-resistant P. aeruginosa and many ESBL-producing Enterobacteriaceae [49]. Another association used to improve the spectrum of antibiotic action is that of piperacillin-tazobactam and vancomycin [50].

Although clavulanic acid, tazobactam, and sulbactam are commercially available BLIs, they exert inhibitory effect against serine- $\beta$-lactamases, mainly belonging to classes $A, C$, and $D$, which means that they are not inhibitors of metallo- $\beta$-lactamases [34]. Regarding metallo- $\beta$-lactamases inhibitors, the most important are the following: (i) thiol derivates, such as thiomandelic acids, which bind at the hydrophobic pocket of the enzyme active site and bind to, or interfere with, the bonding network between the hydrolytic water and the $\mathrm{Zn}^{2+}$ ions [10]; (ii) dicarboxylate, that is, succinic acid, which binds at the dinuclear metal center using one carboxylate to form a monodentate bridge between both zinc ions, and the second carboxylate to bridge between $\mathrm{Zn}^{2+}$ and a conserved Lys residue [51]; (iii) trifluoromethyl ketones and alcohols, the tetrazole portion of whose molecule interacts directly with the active-site $\mathrm{Zn}^{2+}$ ions; (iv) carbapenem analogs; (v) tricyclic natural products; and (vi) penicillin derivatives with C-6-mercaptomethyl substituent [10].

Considering that the bacterial resistance is a health care problem, the development of new $\beta$-lactamase inhibitors or improvement of already-available BLIs is essential. Meropenem-RPX7009 and Biapenem-RPX7009 by Rempex Pharmaceuticals that are both boronate $\beta$-lactamase inhibitors are still in development phase [42]. Although the first citation of boronic acids as serine- $\beta$-lactamases inhibitors was already reported many years ago, they have recently been explored as the next generation of pan- $\beta$-lactamase inhibitors. Trigonal boron (III) compounds behave as Lewis acids and are prone to react with nucleophiles, resulting in tetrahedral covalent adducts able to resist enzymatic hydrolysis [34]. Another example is Avibactam, which is a diazabyclooctanone approved by the U.S. Food and Drug Administration (FDA) to be used in combination with Ceftazidime (AstraZeneca Pharmaceuticals, Forest-Cerexa, Actavis-Allergan) [42] to treat complicated intra-abdominal infections (cIAI), complicated urinary tract infections (cUTI), and hospital-acquired pneumonia (HAP) [52].

The most part of $\beta$-lactamase inhibitors considered in the present review and available in the market is produced through synthetic routes. The exception is CA, which is produced by Streptomyces strains by fermentation. However, the development of biotechnology/bioprocesses in the last decades has shown a new perspective to develop new pharmaceutical products or improve already-established processes. Thus, we will present old and new panoramas to overcome the question of antibiotic resistance using biotechnology. 


\section{Producers of $\beta$-Lactamases Inhibitors}

Streptomyces spp. are aerobic, filamentous, Gram-positive bacteria, which resemble fungi and are obtained naturally in different environments. These microorganisms are able to create a chain of spores developing a multicellular complex that, after the sporulation phase, forms hyphae with multinucleated mycelium [53]. These morphological characteristics make Streptomyces spp. the most adaptable microorganisms found in the soil, given their broad spectrum of metabolite produced and their biotransformation processes.

The discovery of $\beta$-lactamase inhibitors introduced new ways to overcome the problem of antibiotic resistance, through drug research and development [54]. However, as they also contain the same $\beta$-lactam ring, they are as susceptible to time-limited application as the $\beta$-lactam antibiotics [55]. Resistance to the $\beta$-lactam/ $\beta$-lactamase inhibitor combinations especially of Gram-negative microorganisms is an old and clinically difficult situation $[11,56]$ that has stimulated the use of computation-based design methods to develop new $\beta$-lactamase inhibitors [54].

As previously mentioned, sulbactam and tazobactam are obtained by synthetic route [54], while clavulanic acid is a secondary metabolite naturally produced by the actinomycete $S$. clavuligerus [57] that belongs to the class of clavams to which it gives its name.

The discovery of clavams, in which an oxygen substitutes a sulfur of penicillins and cephalosporins, occurred during a screening of microorganisms looking for natural products able to inhibit $\beta$-lactamases $[58,59]$. They are structurally related to CA, which, however, is the only one exerting $\beta$-lactamase inhibitory activity. Such an activity may be related to the peculiar 3R, 5R stereochemistry of CA, while all the other clavams have a $3 S, 5 S$ stereochemistry, although some of them have antibacterial or antifungal characteristics $[57,60]$.

According to Nobary and Jensen [61], S. clavuligerus produces the following 5S clavam compounds in addition to CA: 2-hydroxymethylclavam, 2-formyloxymethylclavam, clavam-2-carboxylic acid, and alanylclavam (Figure 3). Even though not clinically effective, these compounds can be used as precursors to produce CA through a different metabolic route.

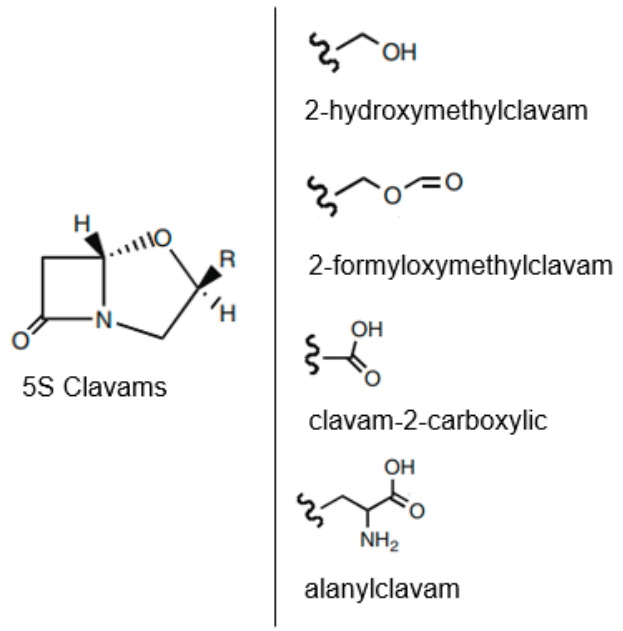

Figure 3. Chemical structure of $5 S$ clavam compounds obtained from Streptomyces clavuligerus. (Adapted from Nobary and Jensen [61]).

CA was identified later in other Streptomyces species, namely Streptomyces jumonjinensis and Streptomyces katsurahamanus, while a great variety of Streptomyces species showed the capacity to produce other clavam metabolites with structures similar to CA (clavaminic acid, valclavam, and clavamycins) [62]. More recently, genome-sequencing projects have resulted in deposits of DNA sequences that suggest that CA biosynthetic capability exists in a wider range of strains, including Streptomyces flavogriseus ATCC 33331 and Saccharomonospora viridis DSM 43017 [61]. The number of 
species that produce non-CA clavams overpasses that of CA producers, so the ability to biosynthesize and distribute CA is rather limited [62].

Studies investigating biosynthetic ways and genes correlated with the production of CA and other clavams have been performed [63-65]. CA biosynthesis involves early and late stages including oxidative reactions catalyzed by 2-oxoglutarate dependent dioxygenases. The "early" steps are largely accepted, but those of the "later" fraction are not understood or are even unknown. Gene clusters for the biosynthesis of CA, $5 \mathrm{~S}$ clavams, and their paralogs have been identified in S. clavuligerus genome sequence. According to Tahlan et al. [66], ceaS2, bls2, pah2, cas2, and oat2 are genes involved in clavaminic acid biosynthesis, thus contributing to both CA and $5 \mathrm{~S}$ clavams productions, while other genes are only involved in that of CA.

CA obtained by fermentation is then recovered from the medium and purified several times. This production has been the subject of intensive research in recent years because of its clinical and commercial importance [61]. According to Costa and Badino [67] and Ünsaldı et al. [65], CA fermentation processes provide low CA concentrations, which hinders its large-scale chemical synthesis. Moreover, the commercial CA feasibility is restricted because of its elaborate production process [68]. Thus, it is important to get higher production rates of this valuable compound applying more powerful fermentations.

According to Viana-Marques et al. [69], certain nutrients present in the culture medium (such as C, N, P, S sources and salts) and compounds produced in the biosynthetic steps can enhance CA production. Additionally, there are many ways to increase CA production such as optimization of bioreactor operation, conditions of agitation and aeration, and medium composition [70].

After fermentation, the CA-containing fermented broth is clarified by centrifugation and/or filtration [71], and the clarified broth subjected to primary extraction steps involving liquid-liquid extraction followed by adsorption procedures. We will discuss the production and purification process to obtain $\beta$-lactamases inhibitors later.

The production of new antibiotics, and investigating and manipulating the biosynthesis routes, represent an important, efficient, and sustainable tool [60], with a chance to discover novel mechanisms of action [72]. To promote the production of new compounds, many strategies have been employed such as cloning and heterologous expression of biosynthetic gene clusters, affecting the regulatory ways, varying culture conditions, and co-culturing two or more organisms together [73].

\subsection{Natural Microorganisms}

The search for bioactive metabolites like novel antibiotics produced by microorganisms for potential use in several industrial applications, mainly in the agricultural and pharmaceutical fields, has become more significant because of the progress of drug/multi-drug resistance in most of pathogenic microbes [74]. Even though several antibiotics used in the clinical practice and agriculture were produced by Streptomycetes, many others were found from natural products produced by this genus and were developed into precious therapeutic agents [62,75].

As mentioned above, Streptomyces members are Gram-positive bacteria that grow in different environments with a filamentous form, such as fungi. Soil is the main niche in which they were isolated and identified as prolific producers of effective bioactive compounds other than antibiotics such as antivirals, anticancers, anti-hypertensives, and immunosuppressives [1,74].

Streptomyces species were considered as the major producers of bioactive compounds for the biotechnology industry [76]. Genome sequence surveys on various actinomycetes indicate that each bacterium is able to produce about 10-fold more secondary metabolites than the wild type selected by screening analysis before the availability of the genome sequence data. This suggests that actinomycetes are still promising sources of novel bioactive compounds [77].

According to Chater [75], Streptomyces are being explored even more intensively in the hope that they will help extensively to the provision of new therapeutic products to face the global threat of antibiotic resistance among pathogenic bacteria, as well as to the supply of other bioactive agents for medical purposes. 
More than 23,000 bioactive secondary metabolites obtained from microorganisms have been found, and over 10,000 of them are produced by actinomycetes [78]. In general, the genome sequencing of actinomycetes isolated from soil, or of marine and plant origin, has resulted in the identification of a range of clusters for secondary metabolites, in the quantity of about 20 to 30 clusters per genome. This report reveals unexpected truths in the discovery of new useful agents [79].

Of the 20 (or more) secondary metabolites produced by S. clavuligerus, many have clinical importance, like cephamycin $\mathrm{C}(\mathrm{CephC})$ and $\mathrm{CA}$, which are synthesized simultaneously through different metabolic routes, rigorously controlling intra- and extracellular factors [80,81].

S. clavuligerus is a great model for analyzing the relations involved in the biosynthesis of secondary metabolites because of its productive diversity [82]; for this reason, it has been used in metabolic engineering to obtain new strains able to overproduce CA. Particularly, amplification of biosynthetic genes encoding specific enzymes can conduct to an earlier and more rational method to upgrade strains with higher antibiotic production [62].

\subsection{Genetically-Modified Microorganisms}

Large-scale obtention of antibiotics by microbial fermentation has been the ground of the industry since the development of penicillin in the 1940s. Amounts of these products are nowadays very prominent after years of strong improvement of strategies as such mutagenesis and selection. These strategies, which contribute for strain enhancement, were early adopted for the penicillin strain. For example, Olano et al. reported in 2008 a penicillin production by Penicillium chrysogenum higher than $70 \mathrm{~g} / \mathrm{L}$, while in 1949 , the original strain produced only $60 \mathrm{mg} / \mathrm{L}$, which represents more than a 1000-fold increase [83].

Random mutagenesis and selection techniques are frequently used to obtain the strain most suitable for industrial fermentations, aiming to get high amounts of secondary metabolites [82]. This advance can be realized through over-expression of overall regulators, pathway-specific regulators, or biosynthetic genes. However, genetic engineering attempts to create high-yield strains of a specific product have rarely been successful; thus, enhancing production is still considered a challenge [64].

Furthermore, the deployment of new technologies such as DNA sequencing, transcription profiling, genomics, proteomics, metabolomics, transcriptomics, and metabolite profiling have offered new chances to engineer strains for obtaining high yields of natural products [83].

The improvement of microbial species is also an important way to decrease the production costs of industrial fermentations. Now, the mutation and selection technique is used frequently with success; however, it is very slow and labor-intensive [64].

According to Li and Townsend [82], the creation of a new generation of highly performant strains by this approach may take at least five years. Techniques of molecular genetics have been improved, and the possibility to change existing ways or make non-native pathways has progressed fast (Table 2). Advances in genetics, transcriptional analysis, proteomics, metabolic reconstructions, and metabolic flux analysis offer genetic engineering the chance to enhance the approaches for strain improvement in a targeted way.

Table 2. Genetic methods applied to improve the production of antibiotics and $\beta$-lactamase inhibitors (Adapted from Adrio and Demain [84]).

\begin{tabular}{|c|c|}
\hline Genetic Method & Secondary Metabolite \\
\hline Protoplast fusion & Penicillin G, cephalosporin C, cephamycin C, clavulanic acid, indolizomycin, rifamycins \\
\hline Metabolic engineering & $\begin{array}{l}\text { Antibiotics (penicillin G, cephalosporin C, cephamycin C, clavulanic acid, } \\
\text { semisynthetic cephalosporins) }\end{array}$ \\
\hline Transposition & Daptomycin, tylosin \\
\hline Combinatorial biosynthesis & Erythromycins, tetracenomycins, tylosin, spiramycins \\
\hline Genome mining & Echinosporamicin-type antibiotics, antifungal compounds (ECO-02301), and so on \\
\hline
\end{tabular}


Most models of CA overproduction have come from manipulation of genes encoding biosynthetic enzymes or transcriptional regulators [62]. CA is obtained by submerged fermentation and then purified from the fermented broth in different ways; however, the most common protocol is centrifugation for cell separation, followed by liquid-liquid extraction with organic solvents and/or adsorption techniques and, finally, chromatography techniques [85].

\section{Production of $\beta$-Lactamase Inhibitors}

\subsection{Biosynthesis of Clavulanic Acid}

Studies carried out by Higgens and Kastner [86] and Brown et al. [87] were the first reports on the production of $\beta$-lactamase inhibitors by S. clavuligerus ATCC27064 and their recovery from the fermented broth. Although more than 40 years have passed since then, their strategy remains one of the most frequently applied to produce important drugs for medicinal use [88].

The biosynthetic pathway to produce CA (Figure 4) has not been fully elucidated, although many intermediates and enzymes have already been isolated. Nonetheless, isotope studies, purification, and characterization of the enzymes involved in the process, together with genetic studies, have contributed to clarify its biosynthetic pathway. Arginine (C5 precursor) and glutaraldehyde-3-phosphate (C3 precursor) were identified as two important precursors for clavulanic acid in S. clavuligerus [89,90].

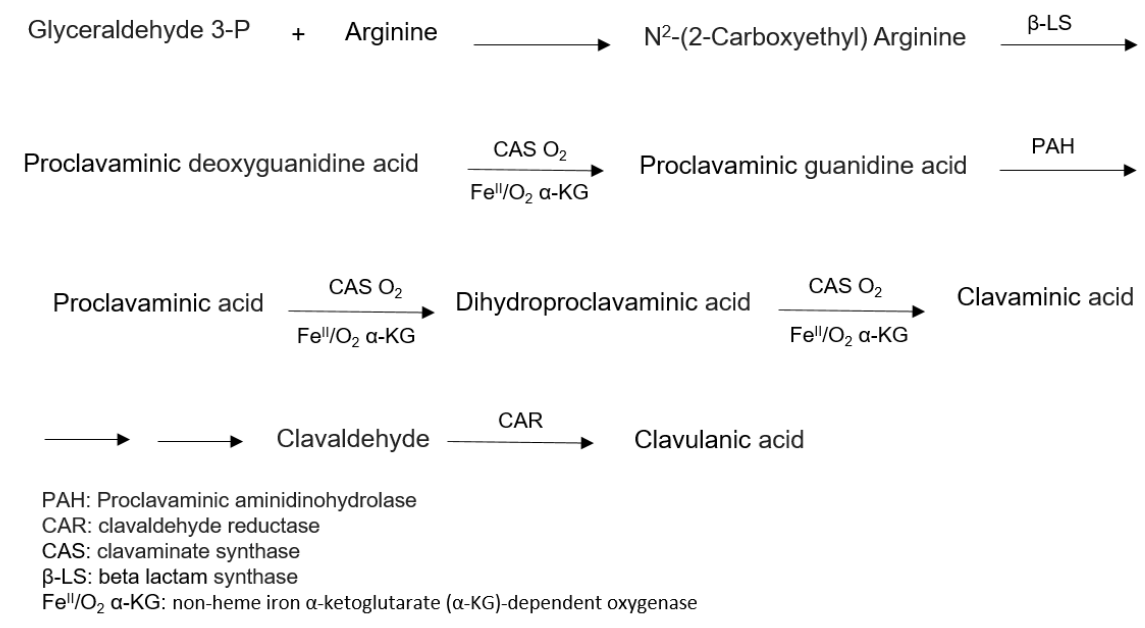

Figure 4. Scheme of clavulanic acid biosynthesis. (Adapted from Oliveira et al. $[89,90])$.

\subsection{Production Process}

After the discovery of $\beta$-lactamase inhibitors with antibacterial activity reported by Brown et al. [87], many studies have been carried out in recent decades regarding the production processes of $\beta$-lactamases inhibitors [70]. Usually, the industrial production of CA is almost entirely based on S. clavuligerus cultivation in complex medium [91]. Because of the clinical importance of this compound, the increase in CA production has been the focus of several studies. Strategies to enhance CA production include optimization of batch or fed-batch operation [92,93], temperature [94-96], agitation and aeration [60,93], and medium composition [70,94,95], as well as the selection of new microbial strains [97].

The productivity of microbial metabolites is closely related to the submerged culture process. The selection of the most suitable medium composition is of primary importance to increase the productivity and decrease the cost of any bioprocess [7]. It is well known that extracellular microbial CA production is greatly influenced by medium components, especially carbon and nitrogen sources [70,94], salts composition [70,91,98], and $\mathrm{pH}[93,94,99]$. However, no single medium has been established to optimize CA production by different strains, because each organism requires different conditions for maximum production, which is mainly controlled by intracellular effectors [100]. 


\subsubsection{Carbon Sources}

Several carbon sources (glycerol, starch, sucrose, and lipid) have been used to produce CA $[70,95,101-103]$. Glycerol plays an important role in CA production as the C3 precursor of the molecule [104]. The formation of the $\mathrm{C} 3$ precursor did in fact appear to be the rate-limiting step of CA synthesis, while excess arginine, which is the C5 precursor, failed to increase CA production [105]. Bellão et al. [80] investigated the effect of carbon source and feeding conditions on the productions of CA and cephamycin C (CephC) by S. clavuligerus. In the experimental range studied, glycerol feeding conditions did not influence maximum CephC production $(566.5 \mathrm{mg} / \mathrm{L})$, whereas maximum CA concentration $(1022 \mathrm{mg} / \mathrm{L})$ was strongly dependent on culture conditions. These results are consistent with those reported by Saudagar and Singhal [93], who obtained higher amounts of clavulanic acid using glycerol in the production medium.

Wang et al. [106] achieved maximum CA production in shake flask batch cultivation at a glycerol concentration of $15.0 \mathrm{~g} / \mathrm{L}$, while Teodoro et al. did so in fed-batch culture at $120 \mathrm{~g} / \mathrm{L}$ [107]. In a fed-batch study carried out in a $10 \mathrm{~L}$ bioreactor to determine the influence of glycerol feeding on CA production by $S$. clavuligerus, the highest CA production $(1.6 \mathrm{~g} / \mathrm{L})$ was obtained using a glycerol concentration of $180 \mathrm{~g} / \mathrm{L}$, highlighting a positive effect of glycerol on CA biosynthesis [102]. Many authors have observed that a glycerol concentration above $15 \mathrm{~g} / \mathrm{L}$ inhibited batch CA biosynthesis [94,100,108]. Viana et al. [94] observed a decrease in CA production by Streptomyces DAUFPE 3060 when glycerol concentration was raised from 5 to $10 \mathrm{~g} / \mathrm{L}$. The better performance of the fed-batch process compared with the batch one is likely due to its capacity to prevent substrate inhibition and metabolite repression, besides controlling the growth rate and prolonging the stationary phase.

The preferred carbon source for CA production are lipids because of the inability of S. clavuligerus to utilize simple carbohydrates such as glucose. Oils are preferred in terms of energy, as they contain approximately 2.4 times the energy of glucose [57]. Several authors have reported that oils may stimulate CA production [93,99,109-113]. Lee and Ho [109] identified palm and palm-kernel oils as the most suitable carbon sources for growth of S. clavuligerus and CA production. Large et al. [110] reported maximum CA production $(80 \mathrm{mg} / \mathrm{L}$ ) in a production medium containing unspecified lipids (C16 and C18 unsaturated and saturated fatty acids). Maranesi et al. [111], studying the use of vegetable oil in CA production by S. clavuligerus ATCC 27064, found the highest CA concentration (753 mg/L) in a medium containing $30 \mathrm{~g} / \mathrm{L}$ soybean oil. Saudagar and Singhal [93] obtained similar CA concentrations in media containing palm oil and soybean oil.

Kim et al. [113] investigated the effect of oils on cell growth and CA production during S. clavuligerus NRRL 3585 fermentation. Triolein, whose fatty acid is oleic acid only, was the best oil source for CA production, but free fatty acids generated from oil hydrolysis affected both CA production and cell growth. In the same work, the authors screened for S. clavuligerus mutants resistant to high oleic acid concentrations and identified a mutant (S. clavuligerus OL13) whose oleic acid minimum inhibitory concentration (MIC $=2.1 \mathrm{~g} / \mathrm{L}$ ) was much higher than that of $S$. clavuligerus NRRL 3585 (0.4 g/L). Not only cell growth was improved, but also maximum CA concentration $(1,950 \mathrm{mg} / \mathrm{L})$ was approximately twice as high as that of the parent strain.

Efthimiou et al. [112] described an increase in CA production when $47 \mathrm{mg} / \mathrm{L}$ olive oil was used instead of $25 \mathrm{mg} / \mathrm{L}$ glycerol as the sole carbon source. In a similar study on the effects of different vegetable oil-based media on cell growth and CA production during S. clavuligerus ATCC 27064 cultivation, Salem-Berkhit et al. observed that three out of eight tested oils supported CA production [99] and that the olive oil-containing medium ensured a CA concentration twice as high as glycerol-containing medium.

The use of vegetable oils as the sole carbon source can support bacterial growth and enhance CA production, but a careful choice of the oil is essential to prevent affecting the CA yield [112]. These findings can be explained with the residual oil levels in culture medium [114] and the high 
oxygen requirement for oil metabolism. Residual oil levels may lead to problems associated with the increased medium viscosity and warrant additional downstream processing [93].

Comparing glycerol and sucrose as the sole carbon source, Lee and Ho [109] observed no production of CA in a glycerol-containing medium, but high production in sucrose-containing medium. Similar findings were reported by Ives and Bushell [105], who observed no CA production in glycerol-containing C-limited medium. Another study by Thakur et al. [101] demonstrated that the addition of dextrin or glycerol as the sole carbon source neither improved nor decreased CA production. However, two studies reported a totally different observation, that is, a glycerol-containing basal medium allowed for a maximum CA level $(348.5 \mathrm{mg} / \mathrm{L})$ about twice as high as a starch-based medium $[80,93]$.

Additionally, two other studies by Saudagar and Singhal [93] and Chen et al. [100] revealed a biphasic dose response of glycerol, whereby CA production was inhibited at either too high or too low concentrations.

\subsubsection{Nitrogen Sources}

Soybean derivatives (flour, protein isolate, and meal) have been used as nitrogen sources for CA production $[7,67,70,94,95,97,106,107]$. To perform a screening of medium constituents for fermentative CA production by S. clavuligerus, Rodrigues et al. [70] performed fermentations using soybean protein isolate (SPI) and soybean flour (SF) as the primary nitrogen source, and obtained higher CA concentration $(437 \mathrm{mg} / \mathrm{L})$ with the former ingredient. On the other hand, with SF, CA production remained steady for a long time likely because this ingredient induced the release of extracellular proteases by $S$. clavuligerus, which hydrolyzed it during the growth phase, providing a steady supply of essential nutrients to the microorganism [115].

Being a by-product of oil extraction, SF has been recognized as a potentially useful and cost-effective ingredient. It consists of approximately $40 \%$ proteins and is rich in other organic and inorganic compounds, thus being a good candidate for a culture medium [116]. According to Chen et al. [102], soybean derivatives, such as soy meal flour and soybean protein hydrolyzates, are excellent components of media for CA production because they contain arginine, the precursor of CA.

Viana et al. [94], in their attempt to investigate the effect of SF concentration on CA production by the new isolate Streptomyces DAUFPE 3060, observed maximum CA production (494 mg/L) at the highest level $(20 \mathrm{~g} / \mathrm{L})$. After optimization by response surface methodology, Marques et al. [95] achieved, with the same strain, a maximum CA concentration as high as $629 \mathrm{mg} / \mathrm{L}$ using $40 \mathrm{~g} / \mathrm{L}$ SF.

Ortiz et al. [7] carried out a study on the influence of the type of soybean derivatives as nitrogen sources on CA production by S. clavuligerus. Using two different media, one containing $20 \mathrm{~g} / \mathrm{L}$ SF and the other $20 \mathrm{~g} / \mathrm{L}$ SPI, they obtained the highest CA production $(698 \mathrm{mg} / \mathrm{L})$ with the former ingredient. On the other hand, Teodoro et al. [107], who investigated the effect of SPI level on CA production, achieved the highest CA yield $(380 \mathrm{mg} / \mathrm{L})$ at intermediate SPI concentration $(20 \mathrm{~g} / \mathrm{L}$ corresponding to $2.95 \mathrm{~g} / \mathrm{L}$ total N).

\subsubsection{Amino Acids as Supplements in Basal Medium}

Arginine and ornithine exert a concentration-dependent stimulation of CA production, and both amino acids are effectively incorporated into the CA molecule [117-119]. The investigation of the role of amino acids as nitrogen sources in CA production began in 1986 [117]. Since then, several studies focusing on the effects of amino acids, mainly arginine and ornithine, have been performed.

The incorporation of arginine into the CA molecule does not establish ornithine as a direct precursor, because the enzyme ornithinecarbamoyl transferase of $S$. clavuligerus exhibits arginase activity, which converts arginine to ornithine [120]. However, Valentine et al. [121] used blocking mutants in the $\arg F$ and $\arg G$ genes, which were unable to convert ornithine into arginine, even though they found a great incorporation of arginine in the CA molecule and a poor incorporation of ornithine. 
This demonstrates that arginine is the direct precursor of CA and indicates that arginase activity does not produce sufficient ornithine to incorporate into CA.

Townsend and Ho [119] suggested arginine and pyruvate as CA precursors. However, studies have demonstrated that exogenous ornithine, rather than arginine, effectively enhances CA production, provided that there is a sufficient amount of C3 precursor [120]. A $270 \%$ increase in CA production was observed intermittently feeding glycerol and ornithine compared with the batch cultivation in shake flasks, and a $150 \%$ increase compared with cultures with glycerol and arginine feeding or when only glycerol was fed [122]. Teodoro et al. [102], who investigated the influence of glycerol and ornithine feeding on CA production by S. clavuligerus in batch bioreactor, observed an increase in CA productivity, but a small decrease in CA concentration, in the presence of ornithine. Rodrigues et al. [70] observed that glutamate and ornithine negatively affected CA production, while arginine and threonine had no influence.

\subsubsection{Salts in Basal Medium}

Compounds containing phosphorus, magnesium, and iron are also included in culture media used for CA production [70,106]. Rodrigues et al. [70] published a study on the nutritional requirements of S. clavuligerus for CA production where they demonstrated that ferrous sulfate is an essential ingredient of the fermentation medium because the enzymes involved in CA biosynthesis are $\mathrm{Fe}^{2+}$-dependent. A medium containing ferrous sulfate allowed for a CA concentration of $437 \mathrm{mg} / \mathrm{L}$, while a formulation without this salt yielded only $41 \mathrm{mg} / \mathrm{L}$.

Phosphate is a crucial growth-limiting nutrient that regulates the synthesis of antibiotics belonging to different groups; therefore, industrial production of antibiotics is carried out at growth-limiting concentrations of inorganic phosphate [57]. Saudagar and Singhal [98] observed that the optimum concentration of $\mathrm{KH}_{2} \mathrm{PO}_{4}$ for CA production $(878 \mathrm{mg} / \mathrm{L})$ was $10 \mathrm{mM}$. According their results, higher $\mathrm{CA}$ values are expected at lower temperatures and $\mathrm{KH}_{2} \mathrm{PO}_{4}$ concentrations.

\subsubsection{Effect of $\mathrm{pH}$}

It has been reported that one of the important characteristics of S. clavuligerus is its strong dependence on the extracellular $\mathrm{pH}$ for cell growth and CA production [93,94,99]. Viana et al. [94], using a fractional factorial design to investigate the influence of the initial medium $\mathrm{pH}$ on $\mathrm{CA}$ production by Streptomyces DAUFPE 3060, observed the highest CA concentration (494 mg/L) at $\mathrm{pH}$ 6.0, while Saudagar and Singhal [93], using a $\mathrm{L}_{25}$ orthogonal array, identified $\mathrm{pH} 7.0$ and 7.5 as the optimum $\mathrm{pH}$ values for CA production $(500 \mathrm{mg} / \mathrm{L})$ and cell growth $(140 \mathrm{mg} / \mathrm{L}$ nucleic acid), respectively. The marked decrease in the $\mathrm{CA}$ yield out of this $\mathrm{pH}$ range suggested the occurrence of CA degradation under either acidic or alkaline conditions.

\subsubsection{Extractive Fermentation of Clavulanic Acid}

CA fermentation processes still present problems such as low CA concentrations $[7,92,93,106]$; thus, it is essential to search for more effective fermentation methods able to increase the production yield of this valuable compound. Moreover, CA recovery is based on a relatively complex downstream protocol, including successive liquid-liquid extraction steps with organic solvents and a final chromatographic step, which results in low purification yields $[68,123]$. Therefore, the search for new environmentally friendly (lower amounts of organic solvents) purification strategies is fundamental to achieve higher yields and lower costs. Liquid-liquid extraction in aqueous two-phase systems (ATPS) is an interesting alternative for this purpose [47].

Typical ATPS are the aqueous two-phase polymer systems (ATPPS), formed by two polymers or one polymer and a salt, which separate into two immiscible phases above their critical solubility. Such systems consist of a light phase (top phase), rich in one polymer, and a heavy phase (bottom phase), rich in the second polymer or the salt [124]. Because of the low cost and large difference in 
hydrophobicity of the two phases, ATPPS, mainly poly(ethylene glycol) (PEG)/salt systems, have been widely used to separate enzymes [125], other proteins [126], and antibiotics [47,68,127].

Some advantages of applying ATPS to whole culture media are the increase in recovery yields, feasibility for continuous operation, reduction of the number of steps, and decrease in the process costs because of joining clarification and partial purification [127]. For most of the ATPS constituted by PEG and salt, the antibiotic is commonly separated into the PEG-rich top phase, whereas the by-products such as amino acids and peptides are discarded into the salt-rich bottom phase [128].

An alternative process has been proposed, which integrates fermentation and extraction with the aim to improve the rate of product formation and production costs. Extractive fermentation or in situ product recovery provides a technological solution to overcome the limitations of product inhibition and low product titer, which are typical drawbacks of biotechnological processes. The concept, as the name suggests, involves integration of an extractive step as the first stage of downstream processing, to remove the product simultaneously to its synthesis. In extractive fermentation using ATPS, cells are considered to be immobilized in one of the phases or at the interface, and the required product to partition into the other phase by proper handling of the system [128].

The advantages of extractive fermentation also include reduction of the toxic effect of product on microbial growth [129] and extended fermentation time [130]. Moreover, continuous product removal during the entire fermentation minimizes the temperature- and $\mathrm{pH}$-dependent degradation of product [131], by reducing its exposure to such damaging conditions. This is particularly beneficial for labile products like CA.

Viana Marques et al. [127] carried out an optimization study according to a $2^{2}$-central composite design to investigate the influence of four variables, specifically, PEG molar mass, PEG and phosphate concentrations, and agitation intensity, on CA extractive fermentation with a PEG/phosphate ATPS. Whereas CA partitioned towards the PEG-rich top phase, cells positioned at the interface. Moreover, it was found that 25\% PEG with molecular weight of $8000 \mathrm{~g} / \mathrm{mol}$ and phosphate salts at $240 \mathrm{rpm}$ were the best conditions for the extractive fermentation, leading to the best results in terms of CA partition coefficient $(K=8.2)$, yield in the PEG-rich phase $(Y=93 \%)$, and productivity $(P=5.3 \mathrm{mg} / \mathrm{L} . \mathrm{h})$.

Panas et al. [132], who attempted the purification of CA produced by S. clavuligerus via submerged fermentation using different ATPS, obtained the highest CA recovery yield (64.91\%) and purification factor (22.70) with PEG-600/sodium polyacrylate-8000 and PEG-600/cholinium chloride, respectively. These results support the use of these systems as effective techniques to purify CA from fermented broth in a single partitioning step.

\section{7. $\beta$-Lactamase Inhibitors in Clinical Practice}

Immediately after the discovery of $\beta$-lactam antibiotics as natural antibacterial compounds, they were effectively modified by the pharmaceutical industry for clinical purposes. However, they even constitute an effective group of antibiotics. With the advance of technologies through rapid bacterial genome sequencing, improvements in protein structure determination, and advanced genetic engineering, many industries started to modify the antibiotic structures leading to the second, third, and fourth generations of these drugs. Nevertheless, the problem of antimicrobial resistance persisted, and combined drug therapies arose [31,32].

Mycobacteria antibiotic resistance is multifactorial, including enzyme inactivation and cell wall impenetrability [133]. Additionally, because this bacteria group developed genetic and epigenetic resistance through selection [132], treatment options for mycobacteria have been restricted and inert for over thirty years [134]. An example is the rapid and global diffusion of genes of strains with multidrug resistance such as NDM-1-producing K. pneumoniae [135].

Co-therapy with $\beta$-lactam antibiotics and $\beta$-lactamase inhibitors, with or without a $\beta$-lactam ring, has shown some success (Table 3) [136-138]. Oxyimino-cephalosporins or carbapenems are still 
potentially very reliable and represent a validated strategy to overcome antimicrobial resistance in Gram-negative and Gram-positive bacteria.

Meanwhile, taking into account that Avibactam (and derivatives) are inhibitors of both class $A$ and class $C$ (and some of class D) serine enzymes, new approaches and new targets are essential to diversify treatment options. The approval of Vabomere (meropenem/vaborbactam) or Avycaz (ceftazidime-avibactam) demonstrates that novel combinations could lead to an amenable successful clinical development.

Table 3. Combinations of $\beta$-lactamase inhibitors and $\beta$-lactam antibiotics of clinical use (Adapted from Docquier and Mangani et al. [34] and Bush [41]).

\begin{tabular}{llll}
\hline B-Lactamase Inhibitor & $\beta$-Lactam Antibiotic & Development Status & References \\
\hline Clavulanic acid & Amoxicillin & Approved by FDA, EMA & {$[139]$} \\
\hline \multirow{2}{*}{ Sulbactam } & Ampicillin & Approved by FDA, EMA & {$[140]$} \\
\cline { 2 - 4 } & ETX2514 & Phase 1 trials completed in 2017 & {$[34]$} \\
\hline \multirow{2}{*}{ Tazobactam } & Piperacillin & Approved by FDA, EMA & {$[141]$} \\
\cline { 2 - 4 } & Ceftolozane & $\begin{array}{l}\text { Approved in 2014 by FDA and } \\
\text { in 2015 by EMA }\end{array}$ & {$[34,142-146]$} \\
\cline { 2 - 4 } & Cefepime & Used in Asia & {$[147]$} \\
\hline Avibactam & Ceftazidime & $\begin{array}{l}\text { Approved in 2015 by FDA and } \\
\text { in 2016 by EMA }\end{array}$ & {$[34,148-159]$} \\
\cline { 2 - 4 } & Aztreonam & Phase 2 in progress & {$[149,153,160,161]$} \\
\cline { 2 - 4 } & Ceftaroline & Phase 2 in progress & {$[149,159,162,163]$} \\
\hline Relebactam (MK7655) & $\begin{array}{l}\text { Imipenem } \\
\text { (+ cilastatin) }\end{array}$ & $\begin{array}{l}\text { Phase 3, cUTI (in progress) } \\
\text { Phase 2 cIAI (completed) }\end{array}$ & {$[164,165]$} \\
\hline Vaborbactam (RPX7009) & Meropenem & Approved in 2017 by FDA & {$[34,166]$} \\
\hline AAI101 & Cefepime & Phase 2 initiated in 2017 & {$[34,167,168]$} \\
\hline RG6080 (OP0595, FPI-1459) & Unknown & Phase 1 complete & {$[165]$} \\
\hline
\end{tabular}

FDA, U.S. Food and Drug Administration; EMA, European Medicines Agency; cUTI, complicated urinary tract infection; cIAI, complicated intra-abdominal infection.

Boronic acids, which have recently been discovered as a new class of pan- $\beta$-lactamase inhibitors, are selective, devoid of toxicity, and able to inhibit both serine- and metallo- $\beta$-lactamases. There is a perspective that these inhibitors could be promising and available for clinical use [34].

Phosphonic and phosphinic acids, which contain an inert C-P bond, constitute a group of bioactive small molecules with great pharmaceutical potential. Among the most known examples are fosfomycin (the only FDA-approved antibiotic to treat acute cystitis during pregnancy) and fosmidomycin (a potent antimalarial agent), as well as glyphosate and phosphinothricin (widely used herbicides). However, the use of phosphonic acids as antibiotics/herbicides led to the occurrence of multiple mechanisms of resistance to them [169].

Possible uses of kinase inhibitors in another field, like immune response to bacterial or viral infections, is being investigated in preclinical studies. The receptor tyrosine kinase inhibitor, approved by the FDA, affects $M$. tuberculosis growth through increased lysosomal targeting and suppression of signal transducer and activator of transcription activation [170]. These drugs could also have the ability to inhibit the survival of other microbes and the replication of viruses and, consequently, to decrease the resistance to drugs in patients with infections [171].

\section{Commercial Use}

Despite the emerging need for new antibiotics, there is no advanced research into new antimicrobial drugs. In 2017, only 39 antibiotics were in stages I and III of progress, an amount 
insufficient to meet the current and planned clinical demand. Further, considering these 39 drugs, only 13 (33\%) will be turn into a marketable drug [172]. Because of growing antibiotic resistance and multiresistance, the mortality rate is expected to reach 10 million by 2050, with an estimated economic cost of US \$100 trillion [173]. As an example, 250,000 people die every year from the drug-resistant tuberculosis, and only $52 \%$ of patients worldwide are successful in treatment. And yet, just two novel antibiotics to treat this disease have reached the market in 70 years.

At first glance, although large companies have some advantages in producing new antibiotics, such as an established research method, sophisticated tools for dosage study, and fast approval by regulatory agencies, they give priority to the development of other drugs for the treatment of other diseases. This occurs because the profit of antibiotic investment is low, representing a market of US $\$ 45$ billion, losing only to drugs used in cardiovascular and central nervous diseases [174].

A further issue is the antibiotic price when it reaches the market. The competition is great with generic drugs that have a far lower price. Therefore, in some instances, large companies transfer responsibility to small business to develop these drugs; for example, this happens with daptomycin, produced by Cubist and licensed by Lilly $[175,176]$.

The United States and Europe are joining forces to reach the purpose of producing 10 to 15 new antibiotics every decade. This initiative is part of a government program that aims to make US \$10-\$30 billion available in the market over the next 10 years [177], which would be a real war against drug resistance. Nevertheless, the main obstacle to these strategies is their implementation, as it often implies public acquisition of the rights to distribute the antibiotic that poses a significant risk to companies and major upfront public costs to support this burden.

\section{Future Perspectives}

Nowadays, multidrug resistance is the biggest concern of government agencies and companies that develop antibiotics. Multidrug resistant tuberculosis affects half a million people every year, requires two years of treatment with success in only few cases, and is frequently observed in sites with low human development index. However, many of the novel drugs that are arriving in the market are not directed to infections caused by antibiotic-resistant pathogens. Additionally, according to Pew Charitable Trust studies, only $31 \%$ of drugs in advanced stages of clinical trials are effective against an ESKAPE pathogen, and only 33\% against the multidrug resistant ones [178].

There are companies and entities around the world that are encouraged to solve the problem of antibiotic resistance. The Global Antibiotic Research and Development Partnership (GARDP), a non-profit organization, is designed to fund research and commercialization of antibiotics. Between 2016-2018, it received funding of more than $€ 5$ million for research on new antimicrobial drugs [179].

The isolation of new microorganisms from different environments, such as actinomycetes and more specifically Streptomycetes, able to produce new substances, may considerably accelerate the development of new treatments. Additionally, genetic engineering application and proteomic techniques could generate high performing strains able to produce new bioactive compounds and, consequently, new powerful antibiotics [65].

Besides that, most of the research did not take into account the interactions among bacterial species, which are used to live in communities in the natural environment. In addition, the leakage of antibiotics into natural environments has the potential to radically alter the evolution of resistance along with the microbial dynamics and structure of the communities. Faced with this, the important collaboration of the Amazon Biotechnology Center (CBA) and TB Alliance in the search for new antibiotic producers, and funds to support for the final phase of clinical trials and regulation of using antibiotics, respectively, are a hope [1].

The risk of "super bugs" resistant to relatively all licensed antibiotics may rise in the future; therefore, constant worldwide surveillance for multidrug-resistant bacteria is urgently required. 
Because of this, strong emphasis on collaboration between companies and governments encourages synergy across the search of new antibiotics and the antibiotic market [1].

\section{Conclusions}

This review focused on a general discussion on the production of $\beta$-lactamase inhibitors by the members of the genus Streptomyces. Antibiotic resistance has been around for some time and has grown quite a bit as a result of increased mutations in genes encoding enzymes such as $\beta$-lactamases, which are responsible for inactivation of $\beta$-lactams antibiotics. The classification of these enzymes was reorganized because of the appearance of new genes and, consequently, new enzymes. In view of the fact that antibiotics used in clinical practice at the time were no longer very effective, $\beta$-lactamase inhibitors have arisen to circumvent the serious problem constituted by the spread of many extended-spectrum $\beta$-lactamases.

Clavulanic acid (CA), the first and most important $\beta$-lactamase inhibitor used in clinical practice to date, was obtained naturally by Streptomyces clavuligerus, while the other two most known inhibitors, Tazobactam and Sulbactam, are of synthetic origin. The CA industrial production has been extensively studied. Several sources of carbon, nitrogen, vitamins, amino acids, and salts were tested in batch or fed-batch and small or large-scale cultivations. The influence of physicochemical parameters such as $\mathrm{pH}$, temperature, agitation, and aeration on fermentation was also investigated for the purpose of improving CA production and reducing time and costs. The most used purification processes are chromatographic methods, aqueous two-phase extraction using polymers and salts, and extraction systems using solvents. Extractive fermentation is a promising emerging technology that integrates the production and extraction stages, thus increasing productivity and reducing time.

Although Streptomyces spp. are known to be excellent producers of antibiotics and $\beta$-lactamase inhibitors, rapid and global diffusion of the genes of strains with multidrug resistance is a concern; thus, it is still a considerable challenge to improving production and reducing costs. In this respect, genetic engineering may make it possible to construct combinations of genes capable of coding new, hitherto unknown antibiotics; what we might call hybrid antibiotics.

Recently, bacteria named "ESKAPE" by WHO have emerged, which are extremely important pathogens that spread high levels of resistance across the world. Faced with this, the search for new producers of antibiotics and $\beta$-lactamase inhibitors and combined drug therapies are emergency alternatives. For this to occur consistently, companies and government must join forces to develop new low-priced antibiotics to solve the problem of antibiotic resistance.

Author Contributions: All authors conceived, drafted and revised the manuscript together.

Funding: This research received no external funding.

Conflicts of Interest: The authors declare no conflict of interest.

\section{References}

1. Procópio, R.E.; Silva, I.R.; Martins, M.K.; Azevedo, J.L.; Araújo, J.M. Antibiotics produced by Streptomyces. Braz. J. Infect. Dis. 2012, 16, 466-471. [CrossRef] [PubMed]

2. Radlinski, L.; Conlon, B.P. Antibiotic efficacy in the complex infection environment. Curr. Opin. Microbiol. 2018, 42, 19-24. [CrossRef] [PubMed]

3. Bhattacharyya, B.; Pal, S.; Sen, S. Anitibiotic production by Streptomyces hygroscopicus $\mathrm{D}_{1.5}$ : Cultural effect. Rev. Microbiol. 1998, 29, 254-257. [CrossRef]

4. Mohanraj, G.; Sekar, T. Isolation and screening of actinomycetes from marine sediments for their potential to produce antimicrobials. Int. J. Life Sci. Pharm. Res. 2013, 2, 115-126.

5. Kirk, S.; Avogmpme-Rossa, C.A.; Bushell, M.E. Growth limiting substrate affects antibiotic production and associated metabolic flues in Streptomyces clavuligerus. Biotechnol. Lett. 2000, 22, 1803-1809. [CrossRef]

6. Gouveia, E.R.; Baptista-Neto, A.; Badino, A.C., Jr.; Hokka, C.O. Optimisation of medium composition for clavulanic acid production by Streptomyces clavuligerus. Biotechnol. Lett. 2001, 23, 157-161. [CrossRef] 
7. Ortiz, S.C.A.; Hokka, C.O.; Badino, A.C., Jr. Utilization of soybean derivatives on clavulanic acid production by Streptomyces clavuligerus. Enzyme Microb. Technol. 2007, 40, 1071-1077. [CrossRef]

8. Ehrlich, J.; Bartz, Q.R.; Smith, R.M.; Joslyn, D.A.; Burkholder, P.R. Chloromycetin, a new antibiotic from a soil actinomycete. Science 1947, 106, 417. [CrossRef] [PubMed]

9. Sethi, S.; Kumar, R.; Gupta, S. Antibiotic production by microbes isolated from soil. Int. J. Pharm. Sci. Res. 2013, 4, 2967-2973. [CrossRef]

10. Drawz, S.M.; Bonomo, R.A. Three Decades of $\beta$-Lactamase Inhibitors. Clin. Microbiol. Rev. 2010, $23,160-201$. [CrossRef] [PubMed]

11. Bush, K.; Bradford, P.A. $\beta$-Lactams and $\beta$-Lactamase Inhibitors: An Overview. Cold Spring Harbor Perspect. Med. 2016, 6, 1-22. [CrossRef] [PubMed]

12. Bradford, P.A. Extended-spectrum $\beta$-lactamases in the 21st century: Characterization, epidemiology, and detection of this important resistance threat. Clin. Microbiol. Rev. 2001, 14, 933-951. [CrossRef] [PubMed]

13. Simpson, I.N.; Harper, P.B.; O'Callaghan, C.H. Principal beta-lactamases responsible for resistance to beta-lactam antibiotics in urinary tract infections. Antimicrob. Agents Chemother. 1980, 17, 929-936. [CrossRef] [PubMed]

14. Borodina, I.; Siebring, J.; Zhang, J.; Smith, C.P.; van Keulen, G.; Dijkhuizen, L.; Nielsen, J. Antibiotic Overproduction in Streptomyces coelicolor A3(2) Mediated by Phosphofructokinase Deletion. J. Biol. Chem. 2008, 283, 25186-25199. [CrossRef] [PubMed]

15. Watve, M.G.; Tickoo, R.; Jog, M.M.; Bhole, B.D. How many antibiotics are produced by the genus Streptomyces? Arch. Microbiol. 2001, 176, 386-390. [CrossRef] [PubMed]

16. Abraham, E.P.; Chain, E. An enzyme from bacteria able to destroy penicillin. Rev. Infect. Dis. 1988, 10, 677-678. [CrossRef] [PubMed]

17. Plough, H.H. Penicillin resistance of Staphylococcus aureus and its clinical implications. Am. J. Clin. Pathol. 1945, 15, 446-451. [CrossRef] [PubMed]

18. Bondi, A., Jr.; Dietz, C.C. Penicillin resistant staphylococci. Proc. Soc. Exp. Biol. Med. 1945, 60, 55-58. [CrossRef] [PubMed]

19. Eriksen, K.R. Studies on induced resistance to penicillin in pneumococcus type I. Acta Pathol. Microbiol. Scand. 1945, 22, 398-405. [CrossRef] [PubMed]

20. Gots, J.S. Production of extracellular penicillin-inactivating substances associated with penicillin resistance in Staphylococcus aureus. Proc. Soc. Exp. Biol. Med. 1945, 60, 165-168. [CrossRef] [PubMed]

21. Miller, C.P.; Bohnhoff, M. Studies on the action of penicillin; development of penicillin resistance by gonococcus. Proc. Soc. Exp. Biol. Med. 1945, 60, 354-356. [CrossRef] [PubMed]

22. Waksman, S.A.; Reilly, H.C.; Schatz, A. Strain specificity and production of antibiotic substances: V. Strain resistance of bacteria to antibiotic substances, especially streptomycin. Proc. Natl. Acad. Sci. USA 1945, 31, 157-164. [CrossRef] [PubMed]

23. Hassan, A.; Usman, J.; Kaleem, F.; Omair, M.; Khalid, A.; Iqbal, M. Evaluation of different detection methods of biofilm formation in the clinical isolates. Braz. J. Infect. Dis. 2011, 15, 305-311. [CrossRef]

24. Allen, H.K.; Donato, J.; Wang, H.H.; Cloud-Hansen, K.A.; Davies, J.; Handelsman, J. Call of the wild: Antibiotic resistance genes in natural environments. Nat. Rev. Microbiol. 2010, 8, 251-259. [CrossRef] [PubMed]

25. Petchiappan, A.; Chatterji, D. Antibiotic Resistance: Current Perspectives. ACS Omega 2017, 2, 7400-7409. [CrossRef]

26. Andersson, D.I.; Hughes, D. Microbiological effects of sublethal levels of antibiotics. Nat. Rev. Microbiol. 2014, 12, 465-478. [CrossRef] [PubMed]

27. Hiltunen, T.; Virta, M.; Laine, A.L. Antibiotic resistance in the wild: An eco-evolutionary perspective. Philos. Trans. R. Soc. B Biol. Sci. 2017, 19, 1-7. [CrossRef] [PubMed]

28. World Health Organization. Antibacterial Agents in Clinical Development: An Analysis of the Antibacterial Clinical Development Pipeline, Including Tuberculosis; WHO: Geneva, Switzerland, 2017.

29. Brown, E.D.; Wright, G.D. Antibacterial drug discovery in the resistance era. Nature 2016, 529, $336-343$. [CrossRef] [PubMed] 
30. Bignell, D.R.D.; Seipke, R.F.; Huguet-Tapia, J.C.; Chambers, A.H.; Parry, R.J.; Loria, R. Streptomyces scabies 87-22 contains a coronafacic acid-like biosynthetic cluster that contributes to plant-microbe interactions. Mol. Plant-Microbe Interact. 2010, 23, 161-175. [CrossRef] [PubMed]

31. Fernandes, P. Antibacterial discovery and development-The failure of success? Nat. Biotechnol. 2006, 24, 1497-1503. [CrossRef] [PubMed]

32. Fischbach, M.A.; Walsh, C.T. Antibiotics for emerging pathogens. Science 2009, 325, 1089-1093. [CrossRef] [PubMed]

33. Ogawara, H. Self-resistance in Streptomyces, with Special Reference to $\beta$-Lactam Antibiotics. Molecules 2016, 21, 605. [CrossRef] [PubMed]

34. Docquier, J.D.; Mangani, S. An update on $\beta$-lactamase inhibitor discovery and development. Drug Resist. Updat. 2018, 36, 13-29. [CrossRef] [PubMed]

35. Coulthurst, S.J.; Barnard, A.M.L.; Salmond, G.P.C. Regulation and biosynthesis of carbapenem antibiotics in bacteria. Nat. Rev. Microbiol. 2005, 3, 295-306. [CrossRef] [PubMed]

36. Santos, V.C.; Pereira, J.F.B.; Haga, R.B.; Rangel-Yagui, C.O.; Teixeira, J.A.C.; Converti, A.; Pessoa, A., Jr. Stability of clavulanic acid under variable $\mathrm{pH}$, ionic strength and temperature conditions. A new kinetic approach. Biochem. Eng. J. 2009, 45, 89-93. [CrossRef]

37. Zeng, X.; Lin, J. Beta-lactamase induction and cell wall metabolism in Gram-negative bacteria. Front. Microbiol. 2013, 4, 128. [CrossRef] [PubMed]

38. Cohen, M.L. Changing patterns of infectious disease. Nature 2000, 406, 762-767. [CrossRef] [PubMed]

39. Munita, J.M.; Arias, C.A. Mechanisms of antibiotic resistance. Microbiol. Spectr. 2016, 4, 1-37.

40. Wang, W.-J.; Wang, Q.; Zhang, Y.; Lu, R.; Zhang, Y.-L.; Yang, K.-W.; Lei, J.E. Characterization of $\beta$-lactamase activity using isothermal titration calorimetry. Biochim. Biophys. Acta 2017, 1861, 2031-2038. [CrossRef] [PubMed]

41. Bush, K. A resurgence of $\beta$-lactamase inhibitor combinations effective against multidrug-resistant Gram-negative pathogens. Int. J. Antimicrob. 2015, 46, 483-493. [CrossRef] [PubMed]

42. Papp-Wallace, K.M.; Bonomo, R.A. New $\beta$-Lactamase inhibitors in the clinic. Infect. Dis. Clin. N. Am. 2016, 30, 441-464. [CrossRef] [PubMed]

43. Bush, K.; Jacoby, G.A.; Medeiros, A. Functional classification scheme for $\beta$-lactamases and its correlation with molecular structure. Antimicrob. Agents Chemother. 1995, 39, 1211-1233. [CrossRef] [PubMed]

44. Bush, K.; Jacoby, G.A. Updated functional classification of beta-lactamases. Antimicrob. Agents Chemother. 2010, 54, 969-976. [CrossRef] [PubMed]

45. Laxminarayan, R.; Matsoso, P.; Pant, S.; Brower, C.; Røttingen, J.-A.; Klugman, K.; Davies, S. Access to effective antimicrobials: A worldwide challenge. Lancet 2016, 387, 168-175. [CrossRef]

46. Bush, K. $\beta$-Lactamase inhibitors from laboratory to clinic. Clin. Microbiol. Rev. 1988, 1, 109-123. [CrossRef] [PubMed]

47. Silva, M.S.C.; de Carvaiho Santos-Ebinuma, V.; Lopes, A.M.; de Oliveira Rangel-Yagui, C. Dextran sulfate/Triton $\mathrm{X}$ two-phase micellar systems as an alternative first purification step for clavulanic acid. Fluid Phase Equilib. 2015, 399, 80-86. [CrossRef]

48. Akova, M. Sulbactam-containing b-lactamase inhibitor combinations. Clin. Microbiol. Infect. 2008, 14, $185-188$. [CrossRef] [PubMed]

49. Jacqueline, C.; Howland, K.; Chesnel, L. In vitro activity of ceftolozane/tazobactam in combination with other classes of antibacterial agents. J. Glob. Antimicrob. Resist. 2017, 10, 326-329. [CrossRef] [PubMed]

50. Balci, C.; Uzun, O.; Arici, M.; Hayran, S.A.; Yuce, D.; Unal, S. Nephrotoxicity of piperacillin-tazobactam combined with vancomycin: Should it be a concern? Int. J. Antimicrob. Agents 2018, in press. [CrossRef] [PubMed]

51. Fast, W.; Sutton, L.D. Metallo- $\beta$-lactamase: Inhibitors and reporter substrates. Biochim. Biophys. Acta 2013, 1834, 1648-1659. [CrossRef] [PubMed]

52. Ball, M.; Boyd, A.; Ensor, G.J.; Evans, M.; Golden, M.; Linke, S.R.; Milne, D.; Murphy, R.; Telford, A.; Kalyan, Y.; et al. Development of a manufacturing route to avibactam, a $\beta$-lactamase inhibitor. Org. Process Res. Dev. 2016, 20, 1799-1805. [CrossRef]

53. Ohnishi, Y.; Ishikawa, J.; Hara, H.; Suzuki, H.; Ikenoya, M.; Ikeda, H.; Yamashita, A.; Hattori, M.; Horinouchi, S. Genome sequence of the streptomycin-producing microorganism Streptomyces griséus IFO 13350. J. Bacteriol. 2008, 190, 4050-4060. [CrossRef] [PubMed] 
54. Drawz, S.M.; Papp-Wallace, K.M.; Bonomo, R.A. New $\beta$-lactamase inhibitors: A therapeutic renaissance in an MDR world. Antimicrob. Agents Chemother. 2014, 58, 1835-1846. [CrossRef] [PubMed]

55. Grigorenko, V.G.; Andreeva, I.P.; Rubtsova, M.Y.; Deygen, I.M.; Antipin, R.L.; Majouga, A.G.; Egorov, A.M.; Beshnova, D.A.; Kallio, J.; Hackenberg, C.; et al. Novel non- $\beta$-lactam inhibitor of b-lactamase TEM-171 based on acylated phenoxyaniline. Biochimie 2017, 132, 45-53. [CrossRef] [PubMed]

56. Thomson, J.M.; Distler, A.M.; Bonomo, R.A. Overcoming resistance to $\beta$-lactamase inhibitors: Comparing Sulbactam to novel inhibitors against clavulanate resistant SHV enzymes with substitutions at Ambler position 244. Biochemistry 2007, 46, 11361-11368. [CrossRef] [PubMed]

57. Saudagar, P.S.; Survase, S.A.; Singhal, R.S. Clavulanic acid: A review. Biotechnol. Adv. 2008, 26, $335-351$. [CrossRef] [PubMed]

58. McGowan, S.J.; Bycroft, B.W.; Salmond, G.P.C. Bacterial production of carbapenems and clavams: Evolution of $\beta$-lactam antibiotic pathways. Trends Microbiol. 1998, 6, 203-208. [CrossRef]

59. Özcengiz, G.; Demain, A.L. Recent advances in the biosynthesis of penicillins, cephalosporins and clavams and its regulation. Biotechnol. Adv. 2013, 31, 287-311. [CrossRef] [PubMed]

60. Hamed, R.B.; Gomez-Castellanos, J.R.; Henry, L.; Ducho, C.; McDonough, M.A.; Schofield, C.J. The enzymes of $\beta$-lactam biosynthesis. Nat. Prod. Rep. 2013, 30, 21-107. [CrossRef] [PubMed]

61. Nobary, S.G.; Jensen, S.E. A comparison of the clavam biosynthetic gene clusters in Streptomyces antibioticus Tü1718 and Streptomyces clavuligerus. Can. J. Microbiol. 2012, 58, 413-425. [CrossRef] [PubMed]

62. Song, J.Y.; Jensen, S.L.; Lee, K.J. Clavulanic acid biosynthesis and genetic manipulation for its overproduction. Appl. Microbiol. Biotechnol. 2010, 88, 659-669. [CrossRef] [PubMed]

63. Ramirez-Malule, H.; Restrepo, A.; Cardona, W.; Junne, S.; Neubauer, P.; Rios-Estepa, R. Inversion of the stereochemical configuration $(3 S, 5 S)$-clavaminic acid into $(3 R, 5 R)$-clavulanic acid: A computationally-assisted approach based on experimental evidence. J. Theor. Biol. 2016, 395, 40-50. [CrossRef] [PubMed]

64. Qin, R.; Zhong, C.; Zong, G.; Fua, J.; Pang, X.; Cao, G. Improvement of clavulanic acid production in Streptomyces clavuligerus F613-1 by using a claR-neo reporter strategy. Electron. J. Biotechnol. 2017, 28, 41-46. [CrossRef]

65. Ünsald1, E.; Kurt-Kızıldogan, A.; Voigt, B.; Becher, D.; Ozcengiz, G. Proteome-wide alterations in an industrial clavulanic acid producing strain of Streptomyces clavuligerus. Synth. Syst. Biotechnol. 2017, 2, 39-48. [CrossRef] [PubMed]

66. Tahlan, K.; Anders, C.; Wong, A.; Mosher, R.H.; Beatty, P.H.; Brumlik, M.J.; Griffin, A.; Hughes, C.; Griffin, J.; Barton, B.; et al. $5 \mathrm{~S}$ clavam biosynthetic genes are located in both the clavam and paralog gene clusters in Streptomyces clavuligerus. Chem. Biol. 2007, 14, 131-142. [CrossRef] [PubMed]

67. Costa, C.L.L.; Badino, A.C. Overproduction of clavulanic acid by extractive fermentation. Electron. J. Biotechnol. 2015, 18, 154-160. [CrossRef]

68. Haga, R.B.; Santos-Ebinuma, V.C.; Silva, M.S.C.; Pessoa, A., Jr.; Rangel-Yagui, C.O. Clavulanic acid partitioning in charged aqueous two-phase micellar systems. Sep. Purif. Technol. 2013, 273-278. [CrossRef]

69. Viana-Marques, D.A.; Santos-Ebinuma, V.C.; Pessoa, A., Jr.; Porto, A.L.; Torres, B.R.; Converti, A. Effect of aeration and agitation on extractive fermentation of clavulanic acid by using aqueous two-phase system. Biotechnol. Prog. 2016, 32, 1444-1452. [CrossRef] [PubMed]

70. Rodrigues, K.C.S.; Souza, A.T.; Badino, A.C.; Pedrolli, D.B.; Cerri, M.O. Screening of medium constituents for clavulanic acid production by Streptomyces clavuligerus. Braz. J. Microbiol 2018, in press. [CrossRef] [PubMed]

71. Forte, M.B.S.; Taviot-Guého, C.; Leroux, F.; Rodrigues, M.I.; Maugeri Filho, F. Clavulanic acid separation on fixed bed columns of layered double hydroxides: Optimization of operating parameters using breakthrough curves. Process Biochem. 2016, 51, 509-516. [CrossRef]

72. Kumar, P.S.; Duraipandiyan, V.; Ignacimuthu, S. Isolation, screening and partial purification of antimicrobial antibiotics from soil Streptomyces sp. SCA 7. Kaohsiung J. Med. Sci. 2014, 30, 435-446. [CrossRef] [PubMed]

73. Charusanti, P.; Fong, N.L.; Nagarajan, H.; Pereira, A.R.; Li, H.J.; Abate, E.A.; Su, Y.; Gerwick, W.H.; Palsson, B.O. Exploiting adaptive laboratory evolution of streptomyces clavuligerus for antibiotic discovery and overproduction. PLoS ONE 2012, 7, e033727. [CrossRef] [PubMed]

74. Singh, V.; Haque, S.; Singh, H.; Verma, J.; Vibha, K.; Singh, R.; Jawed, A.; Tripathi, C.K.M. Isolation, screening, and identification of novel isolates of Actinomycetes from India for antimicrobial applications. Front. Microbiol. 2016, 7, 1921. [CrossRef] [PubMed] 
75. Chater, K.F. Recent advances in understanding Streptomyces. F1000Research 2016, 5, 2795. [CrossRef] [PubMed]

76. Al husnan, L.A.; Alkahtani, M.D.F. Molecular Identification of Streptomyces producing antibiotics and their antimicrobial activities. Ann. Agric. Sci. 2016, 61, 251-255. [CrossRef]

77. Weber, T.; Charusanti, P.; Musiol-Kroll, E.M.; Jiang, X.; Tong, Y.; Kim, H.U.; Lee, S.Y. Metabolic engineering of antibiotic factories: New tools for antibiotic production in actinomycetes. Trends Biotechnol. 2015, 33, 15-26. [CrossRef] [PubMed]

78. Balachandran, C.; Duraipandiyan, V.; Arund, Y.; Sangeetha, B.; Emi, N.; Al-Dhabi, N.A.; Ignacimuthu, S.; Inaguma, Y.; Okamoto, A.; Perumal, P.T. Isolation and characterization of 2-hydroxy-9,10-anthraquinone from Streptomyces olivochromogenes (ERINLG-261) with antimicrobial and antiproliferative properties. Rev. Bras. Farmacogn. 2016, 26, 285-295. [CrossRef]

79. Martínez-Burgo, Y.; Álvarez-Álvarez, R.; Pérez-Redondo, R.; Liras, P. Heterologous expression of Streptomyces clavuligerus ATCC 27064 cephamycin C gene cluster. J. Biotechnol. 2014, 186, 21-29. [CrossRef] [PubMed]

80. Bellão, C.; Antonio, T.; Araujo, M.L.G.C.; Badino, A.C. Production of clavulanic acid and cephamycin C by Streptomyces clavuligerus under different fed-batch conditions. Braz. J. Chem. Eng. 2013, 30, 257-266. [CrossRef]

81. Cavallieri, A.P.; Baptista, A.S.; Leite, C.A.; Araujo, M.L.G.C. A case study in flux balance analysis: Lysine, a cephamycin C precursor, can also increase clavulanic acid production. Biochem. Eng. J. 2016, 112, 42-53. [CrossRef]

82. Li, R.; Townsend, C.A. Rational strain improvement for enhanced clavulanic acid production by genetic engineering of the glycolytic pathway in Streptomyces clavuligerus. Metab. Eng. 2006, 8, 240-252. [CrossRef] [PubMed]

83. Olano, C.; Lombó, F.; Méndez, C.; Salas, J.A. Improving production of bioactive secondary metabolites in actinomycetes by metabolic engineering. Metab. Eng. 2008, 10, 281-292. [CrossRef] [PubMed]

84. Adrio, J.L.; Demain, A.L. Recombinant organisms for production of industrial products. Bioeng. Bugs 2010, 1, 116-131. [CrossRef] [PubMed]

85. Hirata, D.B.; Oliveira, J.H.H.L.; Leão, K.V.; Rodrigues, M.I.; Ferreira, A.G.; Giulietti, M.; Barboza, M.; Hokka, C.O. Precipitation of clavulanic acid from fermentation broth with potassium 2-ethyl hexanoate salt. Sep. Purif. Technol. 2009, 66, 598-605. [CrossRef]

86. Higgens, C.E.; Kastner, R.E. Streptomyces clavuligerus sp. nova b-lactam antibiotic producer. Int. J. Syst. Evol. Microbiol. 1971, 21, 326-331. [CrossRef]

87. Brown, A.G.; Butterworth, D.; Cole, M.; Hanscomb, G.; Hood, J.D.; Reading, C.; Rolinson, G.N. Naturally occurring beta-lactamase inhibitors with antibacterial activity. J. Antibiot. 1976, 29, 668-669. [CrossRef] [PubMed]

88. Schmidt, F.R. Optimization and scale up of industrial fermentation processes. Appl. Microbiol. Biotechnol. 2005, 68, 425-435. [CrossRef] [PubMed]

89. Oliveira, J.H.L.; Granato, A.C.; Hirata, D.B.; Hokka, C.O.; Barboza, M. Clavulanic acid and cephamicin C: A perspective of the biosynthesis, isolation and action mechanism. Quim. Nova 2009, 32, 2142-2150. [CrossRef]

90. Townsend, C.A. New reactions in clavulanic acid biosynthesis. Curr Opin Chem Biol. 2002, 6, 583-589. [CrossRef]

91. Ser, H.L.; Law, J.W.F.; Chaiyakunapruk, N.; Jacob, S.A.; Palanisamy, U.D.; Chan, K.G.; Goh, B.H.; Lee, L.H. Fermentation conditions that affect clavulanic acid production in Streptomyces clavuligerus: A systematic review. Front. Microbiol. 2016, 7, 522. [CrossRef] [PubMed]

92. Domingues, L.C.G.; Teodoro, J.C.; Hokka, C.O.; Badino, A.C.; Araujo, M.L.G.C. Optimisation of the glycerol-to-ornithine molar ratio in the feed medium for the continuous production of clavulanic acid by Streptomyces clavuligerus. Biochem. Eng. J. 2010, 53, 7-11. [CrossRef]

93. Saudagar, P.S.; Singhal, R.S. Optimization of nutritional requirements and feeding strategies for clavulanic acid production by Streptomyces clavuligerus. Bioresour. Technol. 2007, 98, 2010-2017. [CrossRef] [PubMed]

94. Viana, D.A.; Carneiro-Cunha, M.N.; Araújo, J.M.; Barros-Neto, B.; Lima-Filho, J.L.; Converti, A.; Pessoa-Júnior, A.; Porto, A.L.F. Screening of variables influencing the clavulanic acid production by Streptomyces DAUFPE 3060 strain. Appl. Biochem. Biotechnol. 2010, 160, 1797-1807. [CrossRef] [PubMed] 
95. Marques, D.A.V.; Carneiro da Cunha, M.N.; Araújo, J.M.; Lima-Filho, J.L.; Converti, A.; Pessoa, A., Jr.; Porto, A.L.F. Optimization of clavulanic acid production by Streptomyces DAUFPE 3060 by response surface methodology. Braz. J. Microbiol. 2011, 42, 658-667. [CrossRef] [PubMed]

96. Costa, C.L.L.; Badino, A.C. Production of clavulanic acid by Streptomyces clavuligerus in batch cultures without and with glycerol pulses under different temperature conditions. Biochem. Eng. J. 2012, 69, 1-7. [CrossRef]

97. Marques, D.A.V.; Santos-Ebinuma, V.C.; Oliveira, P.M.S.; Lima, G.M.S.; Araújo, J.M.; Lima-Filho, J.L.; Converti, A.; Pessoa-Júnior, A.; Porto, A.L.F. Screening of wild type Streptomyces isolates able to overproduce clavulanic acid. Braz. J. Microbiol. 2014, 45, 919-928. [CrossRef]

98. Saudagar, P.S.; Singhal, R.S. A statistical approach using L25 orthogonal array method to study fermentative production of clavulanic acid by Streptomyces clavuligerus MTCC1142. Appl. Biochem. Biotechnol. 2007, 136, 345-359. [CrossRef] [PubMed]

99. Salem-Berkhit, M.M.; Alanazi, F.K.; Alsarra, I.A. Improvement and enhancement of clavulanic acid production in Streptomyces clavuligerus using vegetable oils. Afr. J. Biotechnol. 2010, 9, 6806-6812.

100. Chen, K.C.; Lin, Y.H.; Tsai, C.M.; Hsieh, C.H.; Houng, J.Y. Optimization of glycerol feeding for clavulanic acid production by Streptomyces clavuligerus with glycerol feeding. Biotechnol. Lett. 2002, 24, 455-458. [CrossRef]

101. Thakur, R.; Roy, M.K.; Dutta, N.N.; Bezbaruah, R.L. Coordinate production of cephamycin c and clavulanic acid by Streptomyces clavuligerus. Indian J. Exp. Biol. 1999, 37, 1031-1033. [PubMed]

102. Teodoro, J.C.; Baptista-Neto, A.; Araujo, M.L.G.D.C.; Hokka, C.O.; Badino, A.C. Influence of glycerol and ornithine feeding on clavulanic acid production by Streptomyces clavuligerus. Braz. J. Chem. Eng. 2010, 27, 499-506. [CrossRef]

103. Vasconcelos, E.S.; Lima, V.A.; Goto, L.S.; Cruz-Hernández, I.L.; Hokka, C.O. Clavulanic acid production by the MMS 150 mutant obtained from wild type Streptomyces clavuligerus ATCC 27064. Braz. J. Microbiol. 2014, 44, 1049-1057. [CrossRef] [PubMed]

104. Baggaley, K.H.; Brown, A.G.; Schofield, C.J. Chemistry and biosynthesis of clavulanic acid and other clavams. Nat. Prod. Rep. 1997, 14, 309-333. [CrossRef] [PubMed]

105. Ives, P.R.; Bushell, M.E. Manipulation of the physiology of clavulanic acid production in Streptomyces clavuligerus. Microbiology 1997, 143, 3573-3579. [CrossRef] [PubMed]

106. Wang, Y.H.; Yang, B.; Ren, J.; Dong, M.L.; Liang, D.; Xu, A.L. Optimization of medium composition for the production of clavulanic acid by Streptomyces clavuligerus. Process Biochem. 2005, 40, 1161-1166. [CrossRef]

107. Teodoro, J.C.; Baptista-Neto, A.; Cruz-Hernandez, I.L.; Hokka, C.O.; Badino, A.C. Influence of feeding conditions on clavulanic acid production in fed-batch cultivation with medium containing glycerol. Appl. Microbiol. Biotechnol. 2006, 72, 450-455. [CrossRef] [PubMed]

108. Romero, J.; Liras, P.; Martin, J.F. Dissociation of cephamycin and clavulanic acid biosynthesis in Streptomyces clavuligerus. Appl. Microbiol. Biotechnol. 1984, 20,318-325. [CrossRef]

109. Lee, P.C.; Ho, C.C. Production of clavulanic acid and cephamycin C by Streptomyces clavuligerus in palm-oil medium. World J. Microbiol. Biotechnol. 1996, 12, 73-75. [CrossRef] [PubMed]

110. Large, K.P.; Ison, A.P.; Williams, D.J. The effect of agitation rate on lipid utilisation and clavulanic acid production in Streptomyces clavuligerus. J. Biotechnol. 1998, 63, 111-119. [CrossRef]

111. Maranesi, G.L.; Baptista-Neto, A.; Hokka, C.O.; Badino, A.C. Utilization of vegetable oil in the production of clavulanic acid by Streptomyces clavuligerus ATCC 27064. World J. Microbiol. Biotechnol. 2005, 21, 509-514. [CrossRef]

112. Efthimiou, G.; Thumser, A.E.; Avignone-Rossa, C.A. A novel finding that Streptomyces clavuligerus can produce the antibiotic clavulanic acid using olive oil as a sole carbon source. J. Appl. Microbiol. 2008, 105, 2058-2064. [CrossRef] [PubMed]

113. Kim, S.J.; Kim, J.O.; Shin, C.H.; Park, H.W.; Kim, C.W. An approach to strain improvement and enhanced production of clavulanic acid in Streptomyces clavuligerus. Biosci. Biotech. Biochem. 2009, 73, 160-164. [CrossRef] [PubMed]

114. Stowell, J.D. The application of oils and fats in antibiotic processes. In Carbon Substrates in Biotechnology; Stowell, J.D., Beardsmore, A.J., Keevil, C.W., Woodward, J.R., Eds.; IRL Press: Oxford, UK, 1987; pp. $139-159$.

115. Mayer, A.F.; Deckwer, W.D. Simultaneous production and decomposition of clavulanic acid during Streptomyces clavuligerus cultivations. Appl. Microbiol. Biotechnol. 1996, 45, 41-46. [CrossRef] [PubMed] 
116. Joo, H.S.; Chang, C.S. Production of protease from a new alkalophilic Bacillus sp. I-312 grow on soybean meal: Optimization and some properties. Process Biochem. 2005, 40, 1263-1270. [CrossRef]

117. Romero, J.; Liras, P.; Martín, J.F. Utilization of ornithine and arginine as specific precursors of clavulanic acid. Appl. Environ. Microbiol. 1986, 52, 892-897. [PubMed]

118. Romero, J.; Liras, P.; Martín, J.F. Isolation and biochemical characterization of Streptomyces clavuligerus mutants in the biosynthesis of clavulanic acid and cephamycin C. Appl. Microbiol. Biotechnol. 1988, 27, 510-516. [CrossRef]

119. Townsend, C.A.; Ho, M.F. Biosynthesis of clavulanic acid: Origin of $C_{3}$ unit. J. Am. Chem. Soc. 1985, 107, 1065-1066. [CrossRef]

120. De la Fuente, J.L.; Martin, J.F.; Liras, P. New type of hexameric ornithine carbamoyltransferase with arginase activity in the cephamycin producers Streptomyces clavuligerus and Nocardia lactamdurans. Biochem. J. 1996, 15, 173-179.

121. Valentine, B.P.; Bailey, C.R.; Doherty, A.; Morris, J.; Elson, S.W.; Baggaley, K.H.; Nicholson, N.H. Evidence that arginine is a later metabolic intermediate than ornithine in the biosynthesis of clavulanic acid by Streptomyces clavuligerus. Chem. Soc. Chem. Commun. 1993, 15, 1210-1211. [CrossRef]

122. Chen, K.C.; Lin, Y.H.; Wu, J.Y.; Hwang, S.C.J. Enhancement of clavulanic acid production in Streptomyces clavuligerus with ornithine feeding. Enzyme Microb. Technol. 2003, 32, 152-156. [CrossRef]

123. Barboza, M.; Almeida, R.M.; Hokka, C.O. Kinetic studies on clavulanic acid recovery by ion exchange chromatography. Bioseparation 2001, 10, 221-227. [CrossRef] [PubMed]

124. Albertsson, P.A. Partition of Cell Particles and Macromolecules, 3rd ed.; Wiley: New York, NY, USA, 1986.

125. Lima, C.A.; Freitas, A.C.V., Jr.; Lima Filho, J.L.; Converti, A.; Viana Marques, D.A.; Carneiro-da-Cunha, M.G.; Porto, A.L.F. Two-phase partitioning and partial characterization of a collagenase from Penicillium aurantiogriseum URM4622: Application to collagen hydrolysis. Biochem. Eng. J. 2013, 75, 64-71. [CrossRef]

126. Saravanan, S.; Rao, J.R.; Nair, B.U.; Ramasami, T. Aqueous two-phase poly(ethylene glycol)-poly(acrylic acid) system for protein partitioning: Influence of molecular weight, $\mathrm{pH}$ and temperature. Process Biochem. 2008, 43, 905-911. [CrossRef]

127. Viana Marques, D.A.; Pessoa-Júnior, A.; Lima-Filho, J.L.; Converti, A.; Perego, P.; Porto, A.L.F. Extractive fermentation of clavulanic acid by Streptomyces DAUFPE 3060 using aqueous two-phase system. Biotechnol. Prog. 2011, 27, 95-103. [CrossRef] [PubMed]

128. Silva, C.S.; Cuel, M.F.; Barreto, V.O.; Kwong, W.H.; Hokka, C.O.; Barboza, M. Separation of clavulanic acid from fermented broth of aminoacids by an aqueous two-phase system and ion-exchange adsorption. New Biotechnol. 2012, 29, 428-431. [CrossRef] [PubMed]

129. Lu, C.; Dong, J.; Yang, S.T. Butanol production from wood pulping hydrolysate in na integrated fermentation-gas stripping process. Bioresour. Technol. 2013, 143, 467-475. [CrossRef] [PubMed]

130. Lee, J.C.; Park, H.R.; Park, D.J.; Lee, H.B.; Kim, Y.B.; Kim, C.J. Improved production of teicoplanin using adsorbent resin in fermentations. Lett. Appl. Microbiol. 2003, 37, 196-200. [CrossRef] [PubMed]

131. Bersanetti, P.A.; Almeida, R.M.; Barboza, M.; Araújo, M.L.G.; Hokka, C.O. Kinetic studies on clavulanic acid degradation. Biochem. Eng. J. 2005, 23, 31-36. [CrossRef]

132. Panas, P.; Lopes, C.; Cerri, M.O.; Ventura, S.P.; Santos-Ebinuma, V.C.; Pereira, J.F. Purification of clavulanic acid produced by Streptomyces clavuligerus via submerged fermentation using polyethylene glycol/cholinium chloride aqueous two-phase systems. Fluid Phase Equilib. 2017, 450, 42-50. [CrossRef]

133. Smith, T.; Wolff, K.A.; Nguyen, L. Molecular biology of drug resistance in Mycobacterium tuberculosis. Curr. Top. Microbiol. Immunol. 2013, 374, 53-80. [CrossRef] [PubMed]

134. Cole, S.T. Inhibiting Mycobacterium tuberculosis within and without. Philos. Trans. R. Soc. B Biol. Sci. 2016, 371, 1-8. [CrossRef] [PubMed]

135. Wlodarchak, N.; Teachout, N.; Procknow, R.; Beczkiewicz, J.; Schaenzer, A.; Satyshur, K.; Pavelka, M.; Zuercher, B.; Drewry, D.; Sauer, J.D.; et al. Repurposed kinase inhibitors and $\beta$-lactams as a novel therapy for antibiotic resistant. BioRxiv 2017. [CrossRef]

136. Diacon, A.H.; van der Merwe, L.; Barnard, M.; von Groote-Bidlingmaier, F.; Lange, C.; Garcia-Basteiro, A.L.; Sevene, E.; Ballell, L.; Barros-Aguirre, D. Beta-Lactams against tuberculosis-New trick for an old dog? N. Engl. J. Med. 2016, 375, 393-394. [CrossRef] [PubMed] 
137. Ramon-Garcia, S.; Gonzalez Del Rio, R.; Villarejo, A.S.; Sweet, G.D.; Cunningham, F.; Barros, D.; Ballell, L.; Mendoza-Losana, A.; Ferrer-Bazaga, S.; Thompson, C.J. Repurposing clinically approved cephalosporins for tuberculosis therapy. Sci. Rep. 2016, 6, 34293. [CrossRef] [PubMed]

138. Veziris, N.; Truffot, C.; Mainardi, J.L.; Jarlier, V. Activity of carbapenems combined with clavulanate against murine tuberculosis. Antimicrob. Agents Chemother. 2011, 55, 2597-2600. [CrossRef] [PubMed]

139. Nitsch-Osuch, A.; Kuchar, E.; Zycinska, K.; Gyrczuk, E.; Miskiewicz, K.; Korzeniewski, K. Implementation of hospital's antibiotic policy decreases antimicrobial use in the general pediatric ward. Adv. Exp. Med. Biol. 2015, 857, 67-74. [CrossRef] [PubMed]

140. Urban, C.; Go, E.; Mariano, N.; Berger, B.J.; Avraham, I.; Rubin, D.; Rahal, J.J. Effect of sulbactam on infections caused by imipenem-resistant Acinetobacter calcoaceticus biotype anitratus. J. Infect. Dis. 1993, 167, 448-451. [CrossRef] [PubMed]

141. Brunetti, L.; Poustchi, S.; Cunningham, D.; Toscani, M.; Nguyen, J.; Lim, J.; Ding, Y.; Nahass, R.G. Clinical and economic impact of empirical extended-infusion piperacillin-Tazobactam in a community medical center. Ann. Pharmacother. 2015, 49, 754-760. [CrossRef] [PubMed]

142. Farrell, D.J.; Flamm, R.K.; Sader, H.S.; Jones, R.N. Antimicrobial activity of ceftolozane-Tazobactam tested against Enterobacteriaceae and Pseudomonas aeruginosa with various resistance patterns isolated in U.S. hospitals (2011-2012). Antimicrob. Agents Chemother. 2013, 57, 6305-6310. [CrossRef] [PubMed]

143. Sutherland, C.A.; Nicolau, D.P. Susceptibility profile of ceftolozane/tazobactam and other parenteral antimicrobials against Escherichia coli, Klebsiella pneumoniae, and Pseudomonas aeruginosa from US hospitals. Clin. Ther. 2015, 37, 1564-1571. [CrossRef] [PubMed]

144. Sader, H.S.; Farrell, D.J.; Castanheira, M.; Flamm, R.K.; Jones, R.N. Antimicrobial activity of ceftolozane/ tazobactam tested against Pseudomonas aeruginosa and Enterobacteriaceae with various resistance patterns isolated in European hospitals (2011-12). J. Antimicrob. Chemother. 2014, 69, 2713-2722. [CrossRef] [PubMed]

145. Estabrook, M.; Bussell, B.; Clugston, S.L.; Bush, K. In vitro activity of ceftolozane-tazobactam as determined by broth dilution and agar diffusion assays against recent U.S. Escherichia coli isolates from 2010 to 2011 carrying CTX-M-type extended-spectrum $\beta$-lactamases. J. Clin. Microbiol. 2014, 52, 4049-4052. [PubMed]

146. Solomkin, J.; Hershberger, E.; Miller, B.; Popejoy, M.; Friedland, I.; Steenbergen, J.; Yoon, M.; Collins, S.; Yuan, G.; Barie, P.S.; et al. Ceftolozane/tazobactam plus metronidazole for complicated intra-abdominal infections in an era of multidrug resistance: Results from a randomized, double-blind, phase 3 trial (ASPECT-cIAI). Clin. Infect. Dis. 2015, 60, 1462-1471. [CrossRef] [PubMed]

147. Kaur, R.; Gautam, V.; Singhal, L.; Ray, P. Antimicrobial activity of cefepime-tazobactam combination tested against clinical isolates of Enterobacteriaceae. J. Antibiot. 2014, 67, 603-604. [CrossRef] [PubMed]

148. Lahiri, S.D.; Mangani, S.; Jahic, H.; Benvenuti, M.; Durand-Reville, T.F.; De Luca, F.; Ehmann, D.E.; Rossolini, G.M.; Alm, R.A.; et al. Molecular basis of selective inhibition and slow reversibility of avibactam against class D carbapenemases: A structure-guided study of OXA-24 and OXA-48. ACS Chem. Biol. 2015, 10, 591-600. [CrossRef] [PubMed]

149. Li, H.; Estabrook, M.; Jacoby, G.A.; Nichols, W.W.; Testa, R.T.; Bush, K. In vitro susceptibility of characterized $\beta$-lactamase-producing strains tested with avibactam combinations. Antimicrob. Agents Chemother. 2015, 59, 1789-1793. [CrossRef] [PubMed]

150. Levasseur, P.; Girard, A.M.; Miossec, C.; Pace, J.; Coleman, K. In vitro antibacterial activity of the ceftazidime-avibactam combination against Enterobacteriaceae, including strains with well characterized $\beta$-lactamases. Antimicrob. Agents Chemother. 2015, 59, 1931-1934. [CrossRef] [PubMed]

151. Castanheira, M.; Mills, J.C.; Costello, S.E.; Jones, R.N.; Sader, H.S. Ceftazidime-avibactam activity tested against Enterobacteriaceae isolates from U.S. hospitals (2011 to 2013) and characterization of $\beta$-lactamase-producing strains. Antimicrob. Agents Chemother. 2015, 59, 3509-3517. [CrossRef] [PubMed]

152. Berkhout, J.; Melchers, M.J.; van Mil, A.C.; Nichols, W.W.; Mouton, J.W. In vitro activity of ceftazidime-avibactam combination in in vitro checkerboard assays. Antimicrob. Agents Chemother. 2015, 59, 1138-1144. [CrossRef] [PubMed]

153. Wang, X.; Zhang, F.; Zhao, C.; Wang, Z.; Nichols, W.W.; Testa, R.; Li, H.; Chen, H.; He, W.; Wang, Q.; et al. In vitro activities of ceftazidime-avibactam and aztreonam-avibactam against 372 Gram-negative bacilli collected in 2011 and 2012 from 11 teaching hospitals in China. Antimicrob. Agents Chemother. 2014, 58, 1774-1778. [CrossRef] [PubMed] 
154. Sader, H.S.; Castanheira, M.; Flamm, R.K.; Farrell, D.J.; Jones, R.N. Antimicrobial activity of ceftazidime- avibactam against Gram-negative organisms collected from U.S. medical centers in 2012. Antimicrob. Agents Chemother. 2014, 58, 1684-1692. [CrossRef] [PubMed]

155. Flamm, R.K.; Sader, H.S.; Farrell, D.J.; Jones, R.N. Ceftazidime-avibactam and comparator agents tested against urinary tract isolates from a global surveillance program (2011). Diagn. Microbiol. Infect. Dis. 2014, 80, 233-238. [CrossRef] [PubMed]

156. Flamm, R.K.; Farrell, D.J.; Sader, H.S.; Jones, R.N. Ceftazidime/avibactam activity tested against Gram-negative bacteria isolated from bloodstream, pneumonia, intra-abdominal and urinary tract infections in US medical centres (2012). J. Antimicrob. Chemother. 2014, 69, 1589-1598. [CrossRef] [PubMed]

157. Sader, H.S.; Castanheira, M.; Flamm, R.K.; Mendes, R.E.; Farrell, D.J.; Jones, R.N. Ceftazidime/avibactam tested against Gram-negative bacteria from intensive care unit (ICU) and non-ICU patients, including those with ventilator-associated pneumonia. Int. J. Antimicrob. Agents 2015, 46, 53-59. [CrossRef] [PubMed]

158. Sader, H.S.; Castanheira, M.; Mendes, R.E.; Flamm, R.K.; Farrell, D.J.; Jones, R.N. Ceftazidime-avibactam activity against multidrug-resistant Pseudomonas aeruginosa isolated in U.S. medical centers in 2012 and 2013. Antimicrob. Agents Chemother. 2015, 59, 3656-3659. [CrossRef] [PubMed]

159. Testa, R.; Canton, R.; Giani, T.; Morosini, M.I.; Nichols, W.W.; Seifert, H.; Stefanik, D.; Rossolini, G.M.; Nordmann, P. In vitro activity of ceftazidime, ceftaroline and aztreonam alone and in combination with avibactam against European Gram-negative and Gram-positive clinical isolates. Int. J. Antimicrob. Agents 2015, 45, 641-646. [CrossRef] [PubMed]

160. Biedenbach, D.J.; Kazmierczak, K.; Bouchillon, S.K.; Sahm, D.F.; Bradford, P.A. In vitro activity of aztreonam-avibactam against a global collection of Gram-negative pathogens from 2012 and 2013. Antimicrob. Agents Chemother. 2015, 59, 4239-4248. [CrossRef] [PubMed]

161. Livermore, D.M.; Mushtaq, S.; Warner, M.; Zhang, J.; Maharjan, S.; Doumith, M.; Woodford, N. Activities of NXL104 combinations with ceftazidime and aztreonam against carbapenemase-producing Enterobacteriaceae. Antimicrob. Agents Chemother. 2011, 55, 390-394. [CrossRef] [PubMed]

162. Sader, H.S.; Farrell, D.J.; Flamm, R.K.; Jones, R.N. Activity of ceftaroline and comparator agents tested against Staphylococcus aureus from patients with bloodstream infections in US medical centres (2009-2013). J. Antimicrob. Chemother. 2015, 70, 2053-2056. [CrossRef] [PubMed]

163. Flamm, R.K.; Farrell, D.J.; Sader, H.S.; Jones, R.N. Antimicrobial activity of ceftaroline combined with avibactam tested against bacterial organisms isolated from acute bacterial skin and skin structure infections in United States medical centers (2010-2012). Diagn. Microbiol. Infect. Dis. 2014, 78, 449-456. [CrossRef] [PubMed]

164. Blizzard, T.A.; Chen, H.; Kim, S.; Wu, J.; Bodner, R.; Gude, C.; Imbriglio, J.; Young, K.; Park, Y.W.; Ogawa, A.; et al. Discovery of MK-7655, a $\beta$-lactamase inhibitor for combination with Primaxin ${ }^{\circledR}$. Bioorg. Med. Chem. Lett. 2014, 24, 780-785. [CrossRef] [PubMed]

165. Morinaka, A.; Tsutsumi, Y.; Yamada, M.; Suzuki, K.; Watanabe, T.; Abe, T.; Furuuchi, T.; Inamura, S.; Sakamaki, Y.; Mitsuhashi, N.; et al. OP0595, a new diazabicyclooctane: Mode of action as a serine $\beta$-lactamase inhibitor, antibiotic and $\beta$-lactam 'enhancer'. J. Antimicrob. Chemother. 2015, 70, 2779-2786. [CrossRef] [PubMed]

166. Lapuebla, A.; Abdallah, M.; Olafisoye, O.; Cortes, C.; Urban, C.; Quale, J.; Landman, D. Activity of meropenem combined with RPX7009, a novel $\beta$-lactamase inhibitor, against Gram-negative clinical isolates in New York City. Antimicrob. Agents Chemother. 2015, 59, 4856-4860. [CrossRef] [PubMed]

167. Crandon, J.L.; Nicolau, D.P. Comparative potency of cefepime (FEP) and cefepime/AAI101 (FEP/AAI101) against highly resistant Enterobacteriaceae. In Proceedings of the 54th Interscience Conference on Antimicrobial Agents and Chemotherapy (ICAAC), Washington, DC, USA, 5-9 September 2014.

168. Crandon, J.L.; Nicolau, D.P. In vivo activities of simulated human doses of cefepime and cefepime-AAI101 against multidrug-resistant Gram-negative Enterobacteriaceae. Antimicrob. Agents Chemother. 2015, 59, 2688-2694. [CrossRef] [PubMed]

169. Chekan, J.R.; Cogan, D.P.; Nair, S.K. Molecular basis for resistance against phosphonate antibiotics and herbicides. MedChemComm 2016, 7, 28-36. [CrossRef] [PubMed]

170. Sogi, M.K.; Lien, K.A.; Johnson, J.R.; Krogan, N.J.; Stanley, S.A. The tyrosine kinase inhibitor Gefitinib restricts Mycobacterium tuberculosis growth through increased lysosomal biogenesis and modulation of cytokine signaling. ACS Infect. Dis. 2017, 3, 564-574. [CrossRef] [PubMed] 
171. Pandey, R.; Kapur, R. Kinase inhibitors in clinical practice: An expanding world. J. Allergy Clin. Immunol. 2017, 141, 522-524. [CrossRef] [PubMed]

172. Stern, S.C.S.; Franken, L.; Voller, S.; Rentmeister, H.; Grosch, B. Breaking through the Wall: A Call for Concerted Action on Antibiotics Research and Development; The Boston Consulting Group: Berlin, Germany, 2017.

173. The Review on Antimicrobial Resistance. Antimicrobial Resistance: Tackling a Crisis for the Health and Wealth of Nations; The Review on Antimicrobial Resistance: London, UK, 2014; pp. 1-20.

174. Bush, K. Antibacterial drug discovery in the 21st century. Clin. Microbiol. Infect. 2004, 10, 10-17. [CrossRef] [PubMed]

175. Projan, S.J. Why is big pharma getting out of antibacterial drug discovery? Drug Discov. Today 2003, 6, 427-430. [CrossRef]

176. Boggs, A.F.; Miller, G.H. Antibacterial drug discovery: Is small pharma the solution? Clin. Microbiol. Infect. 2004, 10, 32-36. [CrossRef] [PubMed]

177. Ferraro, J.S.; Towse, A.; Mestre-Ferrandiz, J. Incentives for New Drugs to Tackle Anti-Microbial Resistance; Office of Health Economics: London, UK, 2017.

178. The Pew Charitable Trusts. Antibiotics Currently in Clinical Development; The Pew Charitable Trusts: Philadelphia, PA, USA, 2017.

179. Simpkin, V.L.; Renwick, M.J.; Kelly, R.; Mossialos, E. Incentivising innovation in antibiotic drug discovery and development: Progress, challenges and next steps. J. Antibiot. 2017, 70, 1087-1096. [CrossRef] [PubMed]

(C) 2018 by the authors. Licensee MDPI, Basel, Switzerland. This article is an open access article distributed under the terms and conditions of the Creative Commons Attribution (CC BY) license (http://creativecommons.org/licenses/by/4.0/). 